
If you do not need this report after it has serrived your purpose, please return it \$o the dedolbgical
Survey, using the official mailing label at the end

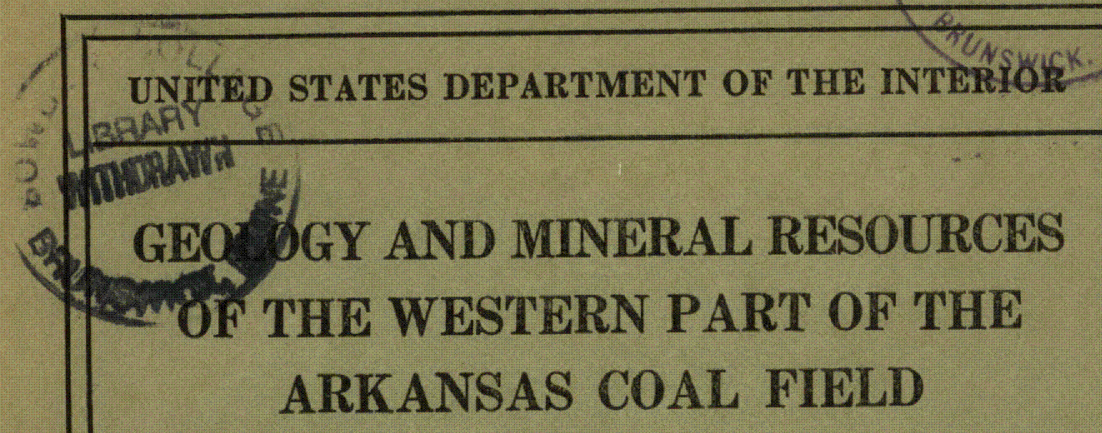

GEOLOGICAL SURVEY BULLETIN 847-E 
UNITED STATES DEPARTMENT OF THE INTERIOR

Harold L. Ickes, Secretary

GEOLOGICAL SURVEY

W. C. Mendenhall, Director

Bulletin 847-E

\section{GEOLOGY AND MINERAL RESOURCES OF} THE WESTERN PART OF THE ARKANSAS COAL FIELD

BY

T. A. HENDRICKS AND BRYAN PARKS

Contributions to economic geology, 1934-36

(Pages 189-224)

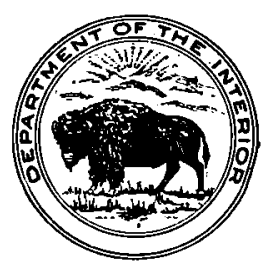

UNITED STATES

GOVERNMENT PAINTING OFFICE WASHINGTON : 1937 



\section{CONTENTS}

Abstract

Introduction . . . .

Scope of report. .

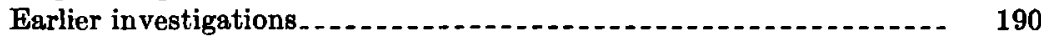

Acknowledgments...

Geography

Land forms

Drainage.............. 192

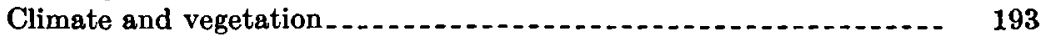

Population and accessibility _._.

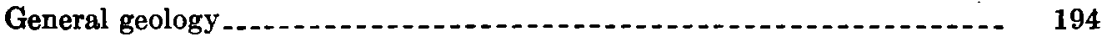

Stratigraphy _...

Age and character of the rocks ....................... 194

Carboniferous system .................. 196

Pennsylvanian series

Atoka formation . . . . . .

Hartshorne sandstone................. 198

McAlester shale................. 199

Savanna sandstone...........

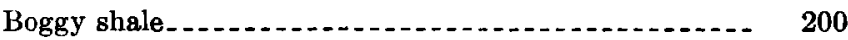

Quaternary (?) system......... 200

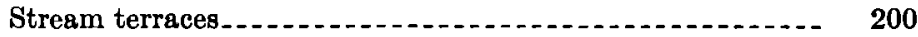

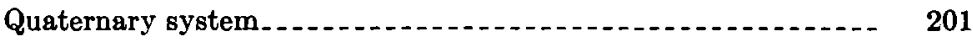

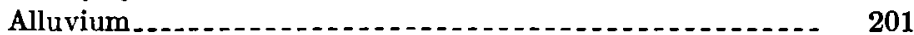

Structure._.

Mineral resources............. 203

Coal

Production

Distribution and thickness of the coal beds.................. 205

Coal below the Lower Hartshorne................... 205

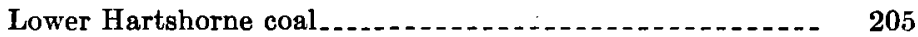

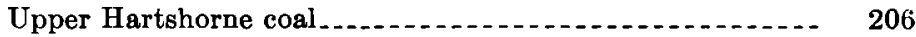

Charleston coal .............. 207

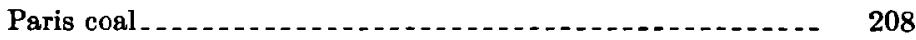

Other coals

Rank, quality, and uses of the coal................. 209

Mining methods................... 209

Natural gas . . . . .

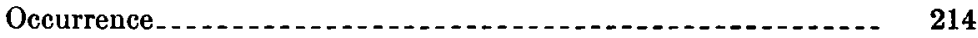

Production .......... 216

Nature of the gas . . .

Gas fields_.......... 217

Mansfield._.

Etna_ .

Vesta....

Lavaca . . . . . . 
Mineral resources-Continued.

Natural gas-Continued.

Gas fields-Continued. Page

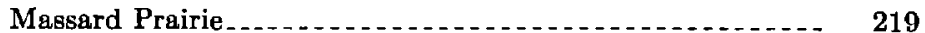

Shibley

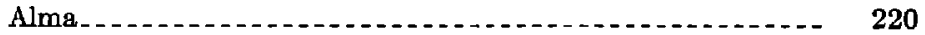

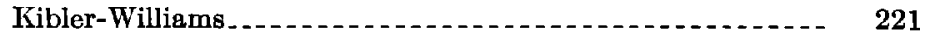

Localities structurally favorable for accumulation of gas _. . _. _ 221

Biswell Hill anticline . . . . . . . . . . . . . . . . . . . . . . . 221

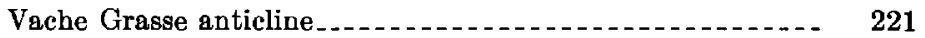

Game Hill anticline............. 222

Closure against Bee Bluff fault.

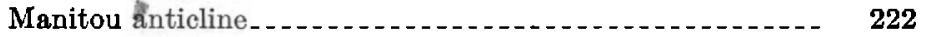

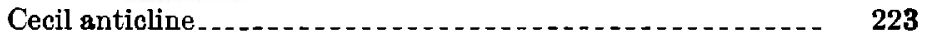

Closure against Mill Creek fault. ................... 223

Closure against Mulberry fault in T. 9 N., R. 31 W. .... 223

Sand and gravel . . . .

Shale suitable for manufacture of brick

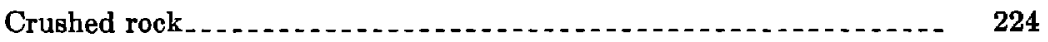

\section{ILLUSTRATION}

Plate 35. Map showing geologic structure and mineral resources of the western part of the Arkansas coal field .............. In pocket 


\title{
GEOLOGY AND MINERAL RESOURCES OF THE WESTERN PART OF THE ARKANSAS COAL FIELD
}

\author{
By T. A. Hendricks and Bryan Parks
}

\begin{abstract}
The western part of the Arkansas coal field covers an area of about 1,100 square miles in Scott, Sebastian, Crawford, Franklin, and Logan Counties, Ark. It lies entirely within the Arkansas Valley region.

The exposed stratified racks of the area belong to the Atoka, Hartshorne, McAlester, Savanna, and Boggy formations, of Pennsylvanian age, and consist of alternating beds of shale and sandstone and some associated coal beds. The total thickness of these formations is about 10,000 feet. Unconformities are present at the base of the Hartshorne and Savanna formations, and numerous minor unconformities probably occur within the formations. Overlying these beds in some parts of the area are deposits of unconsolidated sand, gravel, silt, and clay, which are present on stream terraces and in the more recent alluvial valleys of the streams.

The geologic structure of the area is of two types. The southern part of the area is characterized by long, steeply folded anticlines separated by broader synclines and broken at a few places by reverse faults. The structure of that part of the area is closely related to the structure of the Ouachita Mountains, which lie to the south of the coal field. The northern part of the area is characterized by gentle folds that are broken at many places by normal faults and is structurally similar to the Boston Mountains, which lie north of the coal field.

The most valuable mineral resources of the area are coal and natural gas. The western part of the Arkansas coal field has been a large coal-producing area for about 50 years, and it is estimated that $48,639,784$ tons was produced from 1887 to 1934 . The coal is low-volatile bituminous and is an excellent steam and domestic fuel. All the commercial mining has been confined to three coal bedsthe Lower Hartshorne, the Charleston, and the Paris. Some coal has been mined for local use from other beds. A considerable quantity of coal is still available in the area.

Natural gas has been produced in commercial quantities in eight fields in the area. The producing wells generally have a low initial production, low rock pressure, and long life, but in the Alma field the wells are large initial producers and have high rock pressures, and the probable life of the field is short. The gas is produced from sandstones in the Atoka formation and comes from several different horizons. A total of about 250 to 300 billion cubic feet of gas has been produced in the area since the first well was drilled, in 1902. Small production and shows of gas have been encountered at many places in the area, and several folds favorable for the accumulation of gas have not been adequately tested.

Sand and gravel and shale suitable for the manufacture of brick are present in the area, and some crushed sandstone has been used for road surfacing.
\end{abstract}




\section{INTRODUCTION}

\section{SCOPE OF REPORT}

This report describes the mineral resources of the western part of the Arkansas coal field and considers the features of geologic structure and stratigraphy that are essential to an understanding of the nature of occurrence of the mineral resources. The area (see pl. 35) is an irregular-shaped tract of about 1,100 square miles in Scott, Sebastian, Crawford, Franklin, and Logan Counties, in west-central Arkansas.

The Arkansas coal field, an eastward-trending belt that is about 50 miles wide at the Oklahoma State line and tapers to a point near Russellville, Ark., covers an area of about 1,600 square miles in the Arkansas Valley. It is underlain by a thick series of Pennsylvanian rocks that have been greatly folded and broken and later imperfectly beveled off so that the truncated edges of many beds are now exposed at the surface.

Several beds of coal are exposed at different places in the area, and for many years coal has been mined from beneath the surface throughout the area. For more than 30 years natural gas has been known to occur in several parts of the area, and drilling at suitable places has yielded large supplies of gas.

From March 4 to October 1, 1934, a party of seven men under the direction of T. A. Hendricks, working on an allotment of funds from the Public Works Administration, engaged in mapping in detail the exposed rock formations, locating all coal mines, prospect pits, and gas wells, and collecting all available data on coal mines, gas wells, and holes drilled in exploring coal. C. B. Read, Bryan Parks, J. N. Payne, and W. M. Plaster did the field mapping by plane table and stadia traverse on a scale of 2 inches to the mile. C. J. Finger, Jr., C. O. Hansard, P. A. Shaw, and W. M. Plaster served as instrument men.

T. A. Hendricks and Bryan Parks compiled the maps, sections, and tables, and T. A. Hendricks prepared the text of this report from the data obtained in the course of the field work.

\section{EARITER INVESTIGATIONS}

In 1888 a report by Winslow ${ }^{1}$ on the Arkansas coal field was published by the Arkansas Geological Survey. That report set forth briefly the general features of the geology of the coal field and gave fully the data on the coal that were available at that time.

In 1906 a field party of the United States Geological Survey working under A. J. Collier investigated the geology and coal resources of

\footnotetext{
1 Winslow, Arthur, The geology of the coal regions; a preliminary report upon a portion of the coal regions of Arkansas: Arkansas Ceol. Survey Ann. Rept. for 1888, vol. 3, 1888.
} 
the Arkansas coal field. In the report on that work ${ }^{2}$ the major features of the geology and coal resources were described.

In 1910 Steele $^{3}$ prepared a very detailed and comprehensive report on the coal-mining industry in Arkansas for the Arkansas Geological Survey.

A short report on the Fort Smith-Poteau gas field of western Arkansas and eastern Oklahoma by Smith ${ }^{4}$ was published by the United States Geological Survey in 1914. The geologic structure of a small area in the western part of the Arkansas coal field was described in that report.

In 1927 Croneis ${ }^{5 \cdot}$ compiled all available data on the geology of the Arkansas Paleozoic area for the State Survey and supplemented that compilation by field work in the parts of the area in which data were few. That publication contains much valuable information, particularly that relative to natural-gas production and reserves.

\section{ACKNOWLEDGMENTS}

The writer wishes to express appreciation to the companies and individuals who supplied information that has been invaluable in preparing this report, and to the many mine operators who permitted him to sample the coal in their mines. Particular thanks are due to Messrs. Claude Speegle, State mine inspector; R. E. Welch, consulting mining engineer; A. B. Harper, of the Fort Smith Gas Co.; Leigh Kelly, of the Kelly Trust Co.; Cecil Robinson, of the Arkansas Natural Gas Co.; and to the Western Coal \& Mining Co., the Central Coal \& Coke Co., and the Charleston Coal Co.

\section{GEOGRAPHY}

\section{IAND FORMS}

The western part of the Arkansas coal field lies in the Arkansas Valley region, which is bounded on the north by the Boston Mountains and on the south by the Ouachita Mountains. The area is characterized by alternating ridges and valleys. The shape of the surface has been determined by the attitude and resistance of the rock beds. Throughout the area the rocks have been tilted at various angles, after which they have been imperfectly planed off to a surface of low relief. The soft shale beds have been worn down to valleys and slopes, and the hard sandstone beds show their edges near the crests of long ridges.

In the northwestern part of the area, both north and south of the Arkansas River, the beds at the surface do not differ greatly in resistance, downward planing has been greater than throughout most of the

- Collier, A. J.. The Arkansas coal field: U. S. Geol. Survey Bull. 326, 1907.

- Bteele, A. A., Coal mining in Arkansas, Arkansas Geol. Survey, 1910.

- Bmith, C. D., Structure of the Fort Smith-Poteau gas fleld, Arkansas and Oklahoma: U. S. Geol. Bur vey Bull. 641, pp. 23-33, 1914.

- Croneis, Carey, Geology of the Arkanses Paleozoic area: Arkansas Geol. Survey Bull. 3, 1927. 
remainder of the area, and the surface has been reduced to a plain of low relief with only a few ridges and hills capped by resistant beds standing prominently above it.

At the south side of the coal field are two areas in which the beds of rock lie horizontal or nearly horizontal. In those areas stand the broad eastward-trending Sugarloaf and Poteau Mountains. Those two mountains rise about 2,000 feet above the adjacent valleys, and the crest of Poteau Mountain, 2,665 feet above sea level, is the highest point in the area. The lowest point is on the Arkansas River, where it leaves the area in the northeast corner. It is about 360 feet above sea level and about 2,305 feet lower than the top of Poteau Mountain.

Northwest of the city of Paris, at the east side of the area, two flattopped mesas, Horseshoe and Short Mountains, capped by a resistant bed of sandstone, rise about 500 feet above the surrounding country. Scattered throughout the area are a few conical hills 100 to 300 feet high capped by resistant sandstone beds.

In the west-central part of the area Biswell Hill, a broad, smoothly rounded hill about 9 miles long, rises to a height of about 400 feet. Its entire surface, both the flanks and the crest, is formed by a resistant sandstone bed.

North of the Arkansas River in the eastern part of the area and to a small extent in the extreme western part of the area, the surface consists of broad uplands underlain by resistant sandstone beds and broken by valleys 200 to 400 feet deep and a quarter of a mile to half a mile wide.

Throughout the remainder of the area stretch long, narrow ridges, separated by somewhat wider valleys and breached at intervals by streams. The ridges rise 100 to 300 feet above adjacent valleys, and their crests stand at approximately the same level, both along the trend of the ridges and from any one ridge to those adjacent.

\section{DRAINAGE}

The entire area is drained by the Arkansas River and its tributaries. The Arkansas River pursues a meandering course across the northern part of the area from west to east, and most of its tributaries flow northward or southward into it approximately at right angles.

Most of the southern tributaries of the Arkansas within the area rise within the coal field and are sluggish streams heavily laden with very fine sediment except at stages of very low water. The James Fork of the Poteau River, the largest stream south of the Arkansas, rises on the north slopes of Poteau Mountain and flows northwestward to a point near Hackett, where it enters Oklahoma. In Oklahoma it joins the main Poteau River, which flows northeastward and joins the Arkansas on the Arkansas State line at Fort Smith. In addition to its heavy load of sediment, the James Fork carries much 
water that flows out or is pumped out of coal mines and is consequently strongly acid.

Its waters are unpalatable and will not support fish and other life that is characteristic of unpolluted streams of the area. The other permanent streams south of the Arkansas are Vache Grasse, Big, Sixmile, and Hurricane Creeks. Hurricane Creek and its tributuries drain most of the eastern part of the area that lies south of the river and unlike most of the other streams flows eastward instead of northward.

- All the larger streams that enter the Arkansas River from the $\mathrm{n}$ orth rise within the Boston Mountains north of the coal field and are clear except at times of freshet. They carry larger volumes of water than the streams south of the river. The largest northern tributaries of the Arkansas in the area are Lee Creek, Clear Creek (formerly called Frog Bayou), and the Mulberry River.

Most of the other streams in the area flow only in wet seasons, although a few of them are permanent in their lower courses.

The Arkansas, the James Fork, Lee Creek, Clear Creek, and the Mulberry River all flow in channels that lie about 25 feet below broad flood plains covered by alluvium. In times of flood each of these streams escapes from its banks and its waters spread across its flood plain except in places protected by levees.

\section{CLIMATE AND VEGETATION}

The chief climatic characteristics of the area are its short and, as a rule, moderately cold winters, long hot summers, ample sunshine, moderate extremes of temperature, excessive humidity, and heavy rainfall. The weather during spring and late autumn is generally pleasant. From June to the middle of September many of the nights are sultry and oppressive. During the winter there are many balmy and sunny days. Precipitation is general during the colder months but is more local during the other months, when it usually occurs in connection with thunderstorms. Most of the precipitation falls in the torm of rain and averages about 46 inches a year.

There are a few areas of natural prairie within the western part of the Arkansas coal field, but most of the area is either wooded or has been cleared to supply the demand for tillable land. Most of the rocky hillsides support a growth of blackjack, white and red oak, persimmon, and some hickory. The higher mountains in the southern part of the area and the flat-topped hills north of the Arkansas River in the northern part of the area bear a sprinkling of yellow pine and cedar among the hardwood trees. In the valleys pecan, cottonwood, sycamore, and willow heavily burdened with clambering vines, grow along the streams and lakes and in a few larger areas that have not been cleared to supply the demand for rich tillable land.

$75432-37-2$ 


\section{POPULATION AND ACCESSIBILITY}

The western part of the Arkansas coal field is a rather thickly settled country in which are situated five cities that have populations of more than 1,000 and many smaller towns. Forth Smith, which has a population of 31,429 (1930 census) is the largest city and the industrial center of the area. It is immediately south of the Arkansas River in the extreme western part of the area. Five railroads, the St. Louis-San Francisco, the Missouri Pacific, the Kansas City Southern, the Midland Valley, and the Fort Smith \& Western, have lines into Fort Smith that supply adequate railroad connections with all parts of the country. In addition to these railroads the Chicago, Rock Island \& Pacific passes through Hartford, Mansfield, and Abbott, in the southern part of the district, and the Fort Smith, Subiaco \& Rock Island connects with the Missouri Pacific in Paris and continues eastward from that city. Van Buren, adjacent to Fort Smith on the north side of the Arkansas River; Paris, in the southeastern part of the area; Ozark, in the northeast corner; and Hartford, in the southwestern part, are the other cities of the area. In addition to these cities there are more than 40 towns, villages, and communities distributed rather evenly over the area. All the cities and some of the towns are modern communities supplied with city water, sewerage systems, electricity, and natural gas.

Two national highways pass through the area. One crosses the northern part of the area from Ozark to Fort Smith, where it crosses the State line into Oklahoma. The other crosses the western part of the area from a point north of Alma southward through Van Buren and Fort Smith and thence southward to Abbott, south of which it crosses the boundary of the area. In addition to the national highways there were six excellent State highways in the area in 1934. These highways, together with numerous county roads, make all parts of the area easily accessible.

The transportation facilities and large fuel supplies of the area have combined to make Fort Smith an important industrial center. The other cities and towns are largely dependent on agriculture and coal mining, which, together with the production of natural gas, constitute the major industries of the area.

\section{GENERAL GEOLOGY}

\section{STRATIGRAPHY}

\section{AGE AND CHARACTER OF THE ROCKS}

Except for the terrace deposits and alluvium along the streams the exposed rocks of the western part of the Arkansas coal field belong to the Pennsylvanian series of the Carboniferous system. The section of rocks consists of sandstone beds alternating with thicker beds of shale. Some of the shale beds also contain coals and underclays. 
In general the sandstone beds are very similar and have no lithologic characteristics by which they can be identified from place to place. The shale beds do not have lithologic differences that characterize any single bed from place to place, but although the group of shale beds in the lower part of the stratigraphic column (those in the Atoka formation) cannot be distinguished from each other, they can be distinguished from the shale beds that are present in the younger formations. The conl beds can be identified with reasonable accuracy by their own characteristics and by the sequence of overlying and underlying beds. In addition, at most places the shales associated with the coal beds contain plant fossils that are characteristic of each horizon over a large area and differ from any one horizon to another. Where plant fossils are abundant the stratigraphic position of the beds that contain them can be definitely determined.

The group of sandstones, shales, and coals that are present in the Arkansas coal field extend westward into Oklahoma, where they were originally studied by Taff and Adams, ${ }^{6}$ who divided the column of rocks into a series of formations to which they gave names. Five of the formations extend eastward into Arkansas. They are, from oldest to youngest, the Atoka formation, Hartshorne sandstone, McAlester shale, Savanna sandstone, and Boggy shale. These formations, together with all units within the formations that can be traced laterally, have been mapped in the course of the field work on which this report is based. The formations present, the characteristic lithology of the units within the formations, and the thickness of the units for the southwestern and eastern parts of the area are given in the two columnar sections in plate 35 .

In 1907 the United States Geological Survey published the results of an investigation of the entire Arkansas coal field conducted by a field party working under the direction of A. J. Collier. ${ }^{7}$ In that report some of the formation names mentioned above were used, but the boundaries between the formations were placed at horizons different from those used by Taff and Adams ${ }^{8}$ in the earlier work in Oklahoma. In the field work on which the present report is based the formation boundaries were first traced eastward to the ArkansasOklahoma State line by T. A. Hendricks ${ }^{\circ}$ and were then traced eastward into Arkansas from the previously determined positions at the State line. The Atoka formation and Hartshorne sandstone, as mapped and described by Collier, are identical with the Atoka formation and Hartshorne sandstone of this report. Collier called the McAlester shale the McAlester group and subdivided it into the Spadra

- Tafi, J. A., Geology of the McAlester-Lehigh coal fleld, Indian Territory: U. S. Geol. Survey 19th Ann. Rept., pt. 3, p. 441, 1899. Taff, J. A., and Adams, G. I., Geology of the eastern Choctaw coal fleld, Indian Territory: U. S. Geol. Survey 21st Ann. Rept., pt. 2, p. 273, 1900.

' Collier, A. J., The Arkansas coal field: U. S. Geol. Survey Bull. 326, 1907.

- Taff, J. A., and Adams, G. I . op. cit.

- Hendricks, T. A., Geology and mineral resources of the Howe-Wilburton district, Latimer and LeFlore Connties, Okla.: U. S. Geol. Survey Bull. - (In prepsration). 
shale, Fort Smith formation, and Paris shale, and in addition mapped an overlying sandstone as Savanna sandstone. The correlation between Collier's divisions and those used in this report are given in the table below.

Correlation between formation divisions used by Collier and formation divisions used in this report.

\begin{tabular}{|l|l|}
\hline \multicolumn{1}{|c|}{ Collier (Bull. 326) } & \multicolumn{1}{|c|}{ This report } \\
\hline Savanna sandstone. & Boggy shale. \\
\hline Paris shale. & Savanna sandstone. \\
\hline Fort Smith formation. & McAlester shale. \\
\hline Spadra shale. & Hartshorne sandstone. \\
\hline Hartshorne sandstone. & Atoka formation. \\
\hline Atoka formation. & \\
\hline
\end{tabular}

At many places throughout the area unconsolidated sand, gravel, and clay occur in deposits a few feet to about 50 feet thick above the bedded rocks of Pennsylvanian age. These unconsolidated materials are alluvial deposits laid down by streams in Quaternary (?) and Quaternary time.

\section{CARBONIFEROUS SYSTEM \\ PENISYLIVANIAN SERIES \\ ATOKA FORMATION}

Beds of the Atoka formation are exposed in five places in the area. The largest belt of outcrop lies in the southeast corner of the area. A somewhat smaller area lies along and south of Backbone Ridge between Greenwood and the Arkansas-Oklahoma State line. A small outcrop is present on Massard Prairie southeast of Fort Smith. An elongated belt of outcrop occurs along the south side of Mill Creek Ridge in the north-central parts of the area, and beds of the Atoka formation extend along the entire north side of the area.

In the belt of outcrop along Backbone Ridge about 6,500 feet of the Atoka formation is exposed, and near Mansfield, in the southeastern part of the area, about 3,300 feet of the Atoka crops out at the surface, and an additional 2,700 feet has been penetrated in wells drilled for gas. In the other areas of outcrop only the uppermost beds of the Atoka formation are exposed.

The exposed parts of the Atoka formation consist of alternating beds of sandstone and shale with a few streaks of coal present locally 
in the shale. The sandstones vary greatly in thickness and lithology, both from bed to bed and from place to place in a single bed. In general the sandy zones continue for considerable distances, although a thick sandstone may pass laterally into a sandy shale that is considerably thinner. The sandstones range from coarse-grained, almost white, and pure to fine-grained, brownish, and very shaly. Considerable amounts of mica are present in the sandstones at all places. At some places in the areas sandstone beds in the Atoka formation thicken from 10 to 15 feet to as much as 150 feet in distances of a quarter to half a mile. At those places the base of the sandstone cuts downward across the bedding of the underlying shale in the direction of the thickening. The thicker part of the sandstone was deposited in a stream channel that had cut downward into the underlying shale. A conspicuous example of such a channel sandstone is exposed in the bluff on the north side of the Arkansas River immediately west of the bridge that crosses the river at Ozark. Brownish sandy micaceous shale either overlies or underlies the sandstone beds at most places, and the transition from sandy shale to shale in one direction and from sandy shale to sandstone in the other direction is gradual. The remainder of the formation consists of black slightly gritty, splintery shale that contains much coarse mica. This splintery shale differs greatly in appearance from the shales of the McAlester, Savanna, and Boggy formations that lie higher in the section.

The beds of the Atoka formation that are exposed or have been penetrated by drilling in the northern part of the area vary only slightly in thickness. From the Backbone fault southward, however, the upper part of the Atoka formation thickens rapidly. A thick sandstone bed that is 2,450 feet below the top of the formation near the Backbone fault lies 4,250 feet below. the top of the formation in wells drilled near Mansfield, about 12 miles farther south.

In many exposures near Mansfield and in a few exposures southeast of Greenwood, sandstones in the Atoka formation contain plates of shale as much as 3 inches long and half an inch thick that lie in the sandstone at various angles to the bedding. The plates of shale are similar in appearance to the black shale of the Atoka formation. Their presence in the sandstones indicates that previously deposited A toka shale was being eroded while the sandstone was being deposited. The large size of the plates of shale indicates that they were transported only a short distance before being deposited in the including sandstone. This feature, together with the presence of channels in which some of the sandstones were deposited, indicates that, at least locally, breaks occurred in the deposition of the Atoka beds and that minor unconformities or diastems are present in that formation.

The Atoka formation of the Arkansas coal field is identical with the Atoka formation of the Oklahoma coal field. It contains abundant macerated plant material, and a few thin beds containing poorly 
preserved invertebrate animal remains have been noted. No horizon marked by invertebrate fossils can be traced beyond a single local outcrop, however.

HARTSHORNE SANDSTONE

The Hartshorne sandstone rests on an irregular surface of the Atoka formation, and a minor unconformity probably separates the two formations. The Hartshorne sandstone ranges from about 10 to about 300 feet in thickness in exposures in the western portion of the Arkansas coal field. Where it is thick it is generally coarse-grained, pure, and thick-bedded or massive, and where it is thin it is finegrained, thin-bedded, and shaly. In all exposures, however, fresh surfaces of the sandstone have an ashy-white color that is characteristic and serves to distinguish the Hartshorne from other sandstones in the area, although in some outcrops the next two sandstones above the Hartshorne have a similar appearance for short distances.

The Hartshorne sandstone in Arkansas is defined as the first continuous sandstone underlying the Lower Hartshorne coal. Taff and Adams ${ }^{10}$ defined the Hartshorne sandstone in Oklahoma as extending from the top of the first sandstone below the Upper Hartshorne coal to the base of the first continuous sandstone below the Lower Hartshorne coal. Thus it is apparent that the sandstone lying between the Upper and Lower Hartshorne coals in Oklahoma is not a part of the Hartshorne sandstone as mapped in Arkansas. That sandstone is present only as a lenticular bed at a few places in the extreme southwestern part of the Arkansas coal field, and the lack of continuity of its top makes it unsatisfactory as a formation boundary. In all earlier work in the Arkansas coal field the definition of the Hartshorne sandstone has been identical with that of the present writer.

The fact that the Hartshorne sandstone extends over the entire area without interruption indicates that it was laid down beneath a body of water that extended over the entire area. The presence of thick, coarse-grained facies of the sandstone, alternating with thin, fine-grained, and shaly facies, suggests that channels existed in the sea or lake bottom and that the coarser material transported into the sea or lake was deposited in those channels while the finer materials were more widely distributed and form a blanket of sediment in the interchannel areas.

Invertebrate animal remains are rare in the Hartshorne sandstone, but plant remains are present in great abundance. Most of the plant remains in the sandstone proper are fragments of stems and twigs that probably were transported into the body of water from nearby land areas, although some are of types that grow in shallow water and may have lived in the sea or lake in which the Hartshorne was laid down.

10 Tвfl, J. A., and Adams, G. I., Geology of the eastern Choctaw coal fleld, Indian Territory: U. 8. Geol. Survey 21st Ann. Rept., pt. 2, pp. 274-275, 1000. 
The McAlester shale overlies the Hartshorne sandstone conformably throughout the area. It ranges in thickness from about 1,820 feet in the southwest corner of the area to about 1,050 feet in the east-central part. The bulk of the formation consists of dark gritty shale that is somewhat platy. In the southwestern part of the area five sandstones and five coal beds are present in this shale. In the eastern part of the area it includes only one sandstone and two coal beds.

The Lower Hartshorne coal lies near the base of the McAlester shale. This coal bed is the most valuable one in the Arkansas coal field, because of its thickness and the extent of the area underlain by it, both of which are greater than those of any other coal bed. The Upper Hartshorne coal lies about 50 feet above the base of the McAlester shale but is present only in the southwestern part of the area. This coal may possibly be mined commercially at a few places. The other coal beds in the formation are thin and are not of commer-cial importance.

The sandstones in the McAlester shale are generally thin-bedded, ripple-marked, fine-grained, and gray to buff. Locally, however, the lowest sandstone in the southwestern part of the area and the one sandstone present in the eastern part of the area are coarse-grained, pure, and white. At those places they resemble the coarse-grained thick facies of the Hartshorne sandstone.

A few poorly preserved invertebrate animal remains were noted locally in the McAlester shale, and abundant plant remains are present at a few horizons, notably in the roof shale of the Lower Hartshorne coal. The plant remains are identical with plant remains in the McAlester shale of Oklahoma and corroborate the correctness of the tracing of the formation into Arkansas.

\section{SAVANNA SANDSTONE}

The Savanna sandstone rests with a somewhat irregular contact on the McAlester shale. Near the Arkansas State line, on the part of Sugarloaf Mountain that extends into Oklahoma, the basal sandstone of the Savanna cuts downward across the beds in the upper part of the McAlester shale at an angle of several degrees. These features indicate that at least a minor unconformity is present at the base of the Savanna sandstone.

The formation consists of 1,140 to 1,610 feet of alternating beds of sandstone and sandy shale in which several coal beds are present. The sandstones are generally thin-bedded, ripple-marked, fine-grained, and buff to brown. Locally, however, they are coarse-grained and irregularly bedded. The shales are sandy and gray to brown. Two coal beds are present in the formation in the southwestern part of 
the area, and at least five are present in the eastern part. The Cavanal coal in the southwestern part of the area and the Charleston and Paris coals in the eastern part of the area are the only coals of any possible commercial importance.

A few poorly preserved remains of invertebrate animals and an abundance of well-preserved plant remains are present in the formation. The plant remains, together with the lateral tracing of continuous beds in the formation, served as the basis of correlation of the Savanna sandstone in Arkansas with that formation in Oklahoma.

BOGGY SHALE

The Boggy shale overlies the Savanna sandstone conformably at a few places in the area. Less than 100 feet of Boggy shale is present on the top of Poteau Mountain in the southwestern part of the area. About 500 feet of Boggy shale is present south of Charleston, and about 900 feet is present on Short and Horseshoe Mountains near Paris, in the eastern part of the area.

The part of the formation present in the area consists of dark clay shale and gritty shale, with three sandstone beds that lie about 760 to 900 feet above the base. The shales are poorly exposed, and possibly some coal beds are present in them, though none were seen. The sandstone is coarse-grained, medium-bedded, and buff to brown.

No fossils of any kind were noted in this formation, but fossils may be present and might have been found had exposures of the formation been better or more numerous. The correlation of this formation with the Boggy shale of Oklahoma is based on its similar position above the Savanna sandstone and on the similarity in lithologic character of the beds in the Arkansas and Oklahoma areas.

\section{QUATERNARY (?) SYSTEM}

\section{STREAM TERRACES}

Extensive deposits of gravel, sand, silt, and clay occur about 50 feet above the Arkansas River and on both sides of it in the northern part of the area. They have a maximum thickness of about 50 feet and are made up of silt, clay, and coarser deposits that consist chiefly of quartz, chert, quartzite, sandstone, and other siliceous materials. Some of the sand is probably of local origin, but most of the material is unlike any rocks present in the western part of the Arkansas coal field. It was probably transported into the area from the west by the Arkansas River and from the north by the major tributaries of the Arkansas and was deposited in the alluvial valleys of those streams. Since that time the streams have cut downward and now occupy valleys that lie about 50 feet below their former deposits, which now cover terraces along the sides of the valleys. Similar terraces are present along the courses of many of the streams that flow northward 
from Poteau Mountain, but the material in those terraces was all derived from the beds of rock exposed on Poteau Mountain.

The precise age of the deposits has not been determined, and they are only provisionally considered as of Quaternary age.

\section{QUATERNARY SYSTEM}

\section{ALLOVIOM}

Deposits of alluvium are present in wide areas along the courses of the Arkansas River and its major tributaries, and smaller alluvial deposits are present in the valleys of the smaller streams. The alluvium along the courses of the tributaries of the Arkansas River is mostly silt that ranges in thickness from a featheredge at the sides of the flood plains to about 20 feet in the stream banks. Numerous gas wells have been drilled through the alluvium of the Arkansas River southeast of Van Buren, and many have passed through 30 to 50 feet of silt, which is the type and thickness of alluvium that might be expected on the flood plain of the river. Two wells encountered 255 and 260 feet of sand and gravel. That material probably was deposited in abandoned channels of the river and represents approximately the maximum thickness of alluvium that may be expected.

\section{STRUCTURE}

The Arkansas coal field lies in a long, comparatively narrow structural basin that extends eastward along the Arkansas Valley from the Oklahoma State line and lies between the Boston Mountains on the north and the Ouachita Mountains on the south. The geologic structure is very different in these two mountain areas. The rocks of the Ouachita Mountains have been folded and locally broken or faulted by intense pressure exerted from the south. In the folds and along the faults the beds of rock are now inclined at high angles to their original horizontal position, and in many places they are vertical or even overturned. The rocks of the Boston Mountains, however, have been tilted southward at a low angle to the horizontal, are only gently folded, and are broken by steep faults, along most of which the beds on the north side have been raised in relation to the beds on the south side. Faults along which the movement of the rocks was chiefly horizontal and due to compressive forces, such as the faults of the Ouachita Mountains, are called thrust or reverse faults, and faults along which the movement was chiefly vertical, such as the faults of the Boston Mountains, are called normal faults.

The geologic structure of the western part of the Arkansas coal field is essentially a combination of the structure of the Ouachita Mountains with that of the Boston Mountains. In the southern part of the coal field the rocks have been strongly folded and broken by a few reverse faults. The structure of that part of the area is similar to that of the Ouachita Mountains, which lie adjacent to it on the 
south, but the intensity of the folding and faulting is less than that of the Ouachita Mountains. In the northern part of the coal field the rocks have been gently folded and broken by normal faults. The structure of that part of the area is similar to that of the Boston Mountains, but the folding and faulting are somewhat greater.

The geologic structure of the western part of the Arkansas coal field is highly varied. In the southern part of the area the large, steeply folded Mansfield anticline trends eastward through Hartford and passes south of Mansfield and Abbott. It lies between the broad. shallow Poteau Mountain and Sugarloaf synclines, along whose axes lie the two high mountains from which the synclines were named. North of these structural features lies a belt of anticlinal folding that trends eastward across the entire area and passes a short distance south of Bonanza, Jenny Lind, Greenwood, Chismville, and Paris. The Backbone, Washburn, and Pine Ridge anticlines, which form this belt, are large steep folds with many vertical and locally overturned beds on the north flanks and dips of $65^{\circ}$ or less on the south flanks except in a few small areas where the dips are steeper. The Backbone fault, a reverse fault that extends from the vicinity of Bonanza eastward to a point between Jenny Lind and Greenwood, breaks the rocks along the crest of the Backbone anticline. Several smaller faults are present along the north flanks of the folds, particularly near Jenny Lind and Paris. Throughout the area north of a line extending eastward from Bonanza to Chismville and thence to Paris the rocks have been warped into a series of alternating anticlines and synclines in which the rocks dip at low angles, mostly less than $10^{\circ}$. In general those folds trend eastward, but some trend northeastward, and a very few trend slightly south of east. Most of the anticlines are broken by normal faults that lie approximately parallel to their axes, and the River Ridge fault, a long normal fault that passes south of Alma and Mulberry, lies near and approximately parallel to the axis of the Bectum Hill syncline. A number of small normal faults with various trends are present throughout this part of the area but bear no consistent relationship to the major structural axes.

Some evidence indicates that the formation of the folds in the southern part of the area began at least as early as Atoka time. Sandstones in the Atoka, Hartshorne, and McAlester formations along the flanks of the anticlines in that part of the area contain large plates of shale that lie in the sandstones at various angles to the bedding. The inclination of the plates of shale to the bedding of the sandstone shows that these fragments of shale were deposited in the sand as shale rather than as mud that was changed to shale when the including sand was changed to sandstone. Thus the plates of shale were derived from previously deposited shale beds that were being eroded while the sand was being deposited. In modern streams plates 
of shale can be transported only short distances before disintegrating into mud. This fact indicates that the plates of shale were being eroded from some place or places close to the localities where they are now present. As the fragments of shale are found only in sandstone beds that lie on the flanks of anticlines and close to their axes, the most logical source for the shale is on the crests of the anticlines. For these reasons the writer concludes that the anticlines were being warped upward while the sandstones that contain the shale plates were being deposited and that their crests were sufficiently elevated to be undergoing erosion while the sandstones were being deposited on the flanks of the anticlines. The presence of shale plates in sandstones in the Atoka, Hartshorne, and McAlester formations indicates that the crests of the anticlines rose at least slightly many times during the deposition of the sediments of the coal field.

The folding and faulting in the Arkansas coal field was not completed until after the deposition of the youngest Pennsylvanian rocks present in the area, because even the youngest of those rocks were also folded and faulted.

The details of the structure are shown by structure contours on plate 35 and are not further considered here.

\section{MINERAL RESOURCES}

\section{COAL}

\section{PRODUCTION}

The presence of coal in Arkansas has been known since the days of the earliest settlers, and according to Winslow, ${ }^{11}$ written mention of its occurrence appeared as early as 1818. Prior to 1870 the annual production of coal in Arkansas was about 200 tons, obtained from small strip mines and used almost entirely in blacksmithing. Commercial production began about 1870 , when a steam plant was put into operation at the Old Spadra mine, near Spadra, in the eastern part of the Arkansas coal field. Production in the Coal Hill and Spadra districts began to increase about 1873, when the Little Rock \& Fort Smith Railway was extended through those districts. Prior to 1887 production in the western part of the Arkansas coal field was confined to a few small mines located within wagon-hauling distance of Fort Smith. With the extension of the St. Louis-San Francisco Railway southward from Fort Smith in 1887, extensive mining operations were begun at Jenny Lind, Hackett, and Huntington, in Sebastian County. From that time until 1903 production in the western part of the Arkansas coal field increased progressively.

From 1903 to 1918 the production fluctuated from year to year but was consistently above $1,200,000$ tons. Since 1918 it has decreased

"Winslow, Arthur, The geology of the coal regions-a preliminary report upon a portion of the coal regions of Arkansas: Arkansas Geol. Survey Ann. Redt. for 1888, vol. 3, p. 27, 1888. 
at an irregular rate to the present time. This decrease in production has been due almost entirely to increased competition from natural gas and fuel oil. (See details of production in the table.)

Coal produced in the western part of the Arkansas coal field and total production for the State, 1880-1932, in net tons 1

\begin{tabular}{|c|c|c|c|c|}
\hline Year & $\begin{array}{l}\text { Sebastian } \\
\text { County }\end{array}$ & $\begin{array}{l}\text { Logan } \\
\text { County }\end{array}$ & $\begin{array}{l}\text { Franklin } \\
\text { County }\end{array}$ & $\begin{array}{l}\text { Total pro- } \\
\text { duction for } \\
\text { the State }\end{array}$ \\
\hline $\begin{array}{l}1880 \\
1882 \\
1883 \\
1885 \\
1886 \\
1887\end{array}$ & 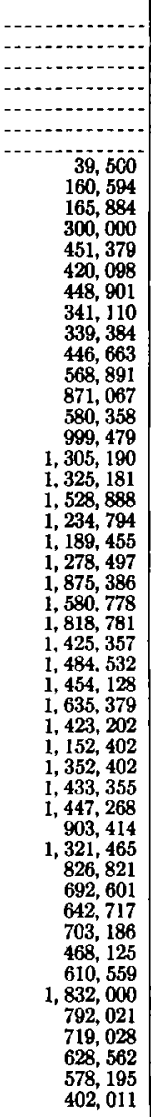 & \begin{tabular}{|r} 
\\
\\
\end{tabular} & 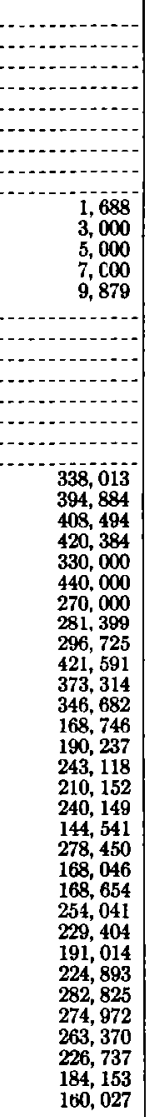 & $\begin{array}{r}14,778 \\
20,000 \\
25,000 \\
56,000 \\
750,000 \\
100,000 \\
125,000 \\
129,600 \\
276,871 \\
279,584 \\
399,888 \\
542,379 \\
535,558 \\
574,763 \\
512,626 \\
598,322 \\
\mathbf{6 7 5}, 374 \\
\mathbf{8 5 6 , 1 9 0} \\
1,205,479 \\
\mathbf{8 4 3}, 554 \\
1,447,945 \\
1,816,136 \\
1,908,966 \\
2,180,336 \\
2,009,451 \\
1,889,848 \\
1,864,268 \\
2,670,438 \\
2,078,357 \\
2,377,157 \\
1,952,968 \\
2,106,789 \\
2,100,819 \\
2,234,107 \\
1,836,540 \\
1,652,106 \\
1,994,915 \\
2,143,579 \\
2,227,369 \\
1,429,020 \\
2,103,596 \\
1,231,777 \\
1,110,046 \\
1,233,242 \\
1,451,503 \\
1,220,039 \\
1,469,017 \\
3,415,904 \\
1,660,973 \\
1,695,108 \\
1,533,434 \\
1,349,905 \\
1,081,494\end{array}$ \\
\hline & $43,198,988$ & $23,567,260$ & $38,425,015$ & $68,317,118$ \\
\hline
\end{tabular}

Production of the western part of the Arkansas coal field:

Sebastian County $\ldots$ Logan County

Logan County Franklin County

$48,639,784$

1 Figures for period 1880-1923 compiled from U. S. Geol. Survey Mineral Resources of the United States. Figures for period 1924-31 compiled from U. S. Bur. Mines Mineral Resources of the United States. Fig. ures for 1932 taken from U. S. Bur. Mines Minerals Yearbook.

Only 1 mine has operated commercially in the part of Logan County that lies outside the area covered by this report, and as its production has been small no deduction has been made for it in the figures given above.

3 Of the total production from Franklin County, 1,873,536 tons came from the portion of the county that lies in the area covered by this report. 
Only three coal beds have been mined commercially in the western part of the Arkansas coal field. These are, from oldest to youngest, the Lower Hartshorne, Charleston, and Paris. About 88.4 percent of the coal mined has come from the Lower Hartshorne bed, about 7.7 percent from the Paris bed, and about 3.9 percent from the Charleston bed. In addition to these beds, numerous thin beds of coal are present, and several have been mined locally. In general these thin coals are less than 18 inches thick, although in a few places one or more of them may exceed 18 inches in thickness for a short distance.

\section{DIRTRIBUTION AND THICKNESS OF THE COAL BEDB}

Coal below the Lower Hartshorne.-A local coal bed is present between the Lower Hartshorne bed and the top of the Hartshorne sandstone in T. $6 \mathrm{~N}$., Rs. 31 and $32 \mathrm{~W}$. This coal lies about 30 feet below the Lower Hartshorne bed and is reported to be 30 inches thick in sec. 13 , T. 6 N., R. 32 W., and sec. 17, T. 6 N., R. 31 W. In these areas small mines, now abandoned, have worked on this bed. At the points where the coal has been mined it is said to be impure and of poor quality. In the other parts of T. $6 \mathrm{~N}$., Rs. 31 and $32 \mathrm{~W}$., available records show less than 10 inches of coal at the horizon of this coal.

Lower Hartshorne coal.- The Lower Hartshorne coal is the most valuable coal bed in the western part of the Arkansas coal field. It underlies a much larger area and has a greater average thickness than any other coal bed. The largest area underlain by this coal lies in Sebastian County and is shown in detail on plate 35. The map shows zones of equal thickness of the coal based on more than 550 sections that have been measured at outcrops, in mines, and in holes drilled to determine the depth to the coal, its thickness, and its purity. In the part of Sebastian County north of Backbone Ridge and Biswell Hill the coal has no partings in about half the sections, a 1- to 6-inch parting in the middle of the bed in about 40 percent of the sections, and a parting greater than 6 inches in the remaining 10 percent of the sections. In the part of the area that extends eastward from Greenwood for about 3 miles a parting that ranges from 1 to 27 inches in thickness irregularly from place to place is present in the middle of the coal in about half the measured sections. From Huntington westward to the western limit of the mine workings and southwestward to the Hofman mine a parting that is 6 inches to more than 3 feet thick is present in the middle of the bed. The parting is so thick that throughout that area only the upper bench of the coal, which is slightly thicker than the lower bench, has been removed. In the remaining parts of the area partings in the coal are either absent or are very thin and extend for only short distances.

The thicknesses of the coal used in compiling the data on which the zones of thickness shown on plate 35 were based were corrected to eliminate any partings present. The system used was that 
adopted by the United States Geological Survey for classifying split coal beds on the public domain. That system of classification was based on the obvious fact than an unbroken coal bed is worth more than a bed containing the same thickness of coal but also containing a clay or shale parting. The Survey therefore prescribes that any parting or bench of bone or impure coal injures the value of the coal of the bed in amount equal to the thickness of the parting. Thus a bed consisting of 18 inches of coal, 6 inches of shale, and 18 inches more of coal is regarded as equivalent to a solid bed 30 inches thick ( 36 inches of coal minus 6 inches of parting equals 30 inches). If a parting is thicker than the thinner adjoining coal bench, that bench is considered to be of no value, and the thickness of the coal in the bed is considered to be that of the thicker bench.

The areas of mine workings shown on plate 35 were obtained from all mine maps filed with the State mine inspector and brought up to date as of July 1,1934 . All mines shown on plate 35 as having no mine workings are wagon mines of small extent, except the Pendergrass shaft, in sec. 5, T. 6 N., R. 32 W., which is a new mine and has as yet removed very little coal. The greater part of the area of mine workings may be considered as completely mined out, although some coal may be removed from pillars in a few of the operating and recently abandoned mines.

Throughout the areas in Crawford, Franklin, and Logan Counties that are underlain by the Lower Hartshorne coal, data on the thickness of the coal are few. The few available measured sections and all reports of thickness indicate that the Lower Hartshorne coal is about 18 inches thick throughout those areas, and only a few small mines have operated on that coal.

The structure contours on plate 35 are drawn on the top of the Lower Hartshorne coal and show the altitude of the coal in relation to sea level. In order to determine the depth from the surface to the Lower Hartshorne coal at any point it is necessary to determine the altitude of the surface at that point and then subtract the altitude of the coal from the altitude of the surface.

Upper Hartshorne coal.-In T. 5 N., Rs. 31 and 32 W., a coal bed occurs 40 to 90 feet above the Lower Hartshorne. No outcrop of this coal was seen, but it has been recorded in many drill holes. Wherever this coal is present it is separated from the Lower Hartshorne by shale and sandstone. The sandstone is lenticular and similar in appearance to the Hartshorne sandstone. Both the position of this coal and the character of the underlying beds are similar to those features for the Upper Hartshorne coal in Oklạhoma, and the writer believes this local coal in Arkansas to be the equivalent of the Upper Hartshorne. Where this coal has been encountered in drill holes, it has been logged as dirty or bony coal if more than 18 
inches thick. This Upper Hartshorne coal may possibly be worked locally in the future, but it is not likely to be of commercial importance.

Charleston coal.-The Charleston coal occurs in four separated basins in the western part of the Arkansas coal field (see pl. 35). The westernmost of these four areas is in the Central syncline just south of the town of Central, in T. 7 N., Rs. 30 and 31 W., where the Charleston coal underlies an area of about $3 \frac{1}{2}$ square miles. This coal ranges from 12 to 18 inches in thickness in measured sections in the Central syncline and has been mined in six small strip pits and four small slope mines. Any future mining in this area will probably consist of small-scale operations, because of the thinness of the coal bed.

The largest area of occurrence of the Charleston coal is in the Bloomer syncline and the adjacent northeast end of the Greenwood syncline. This area, underlain by the Cbarleston coal, extends from sec. 3, T. 6 N., R. 30 W., northeastward to sec. 29 , T. 7 N., R. 29 W., and thence eastward to the east side of sec. 25 , T. 7 N., R. 28 W., and contains a total of about 40 square miles. Measured sections and reported thicknesses indicate that the Charleston coal is about 18 inches thick throughout this basin. In 16 measured sections scattered along the outcrop in the basin the coal ranges from 15 to 22 inches in thickness. Many small mines and strip pits have operated in the Charleston coal in this basin, and if its thickness is as consistently near 18 inches as is indicated by the scattered measured sections, the coal in this basin may possibly be mined commercially in the future.

The third area underlain by the Charleston coal lies about 3 miles northeast of the town of Charleston, in the Charleston syncline, and covers about 3 square miles. The coal has been removed beneath about 1 square mile of that area in large strip mines operated by the Charleston and the McMillan coal companies. Numerous sections measured in the strip pits and in drill holes show the coal to be 14 to 17 inches thick, with a few sections as low as 4 inches or as high as 20 inches. A considerable amount of the remaining coal in this basin may be mined in strip pits in the future.

The fourth area of occurrence of the Charleston coal is around the west end of the Paris syncline. The outcrop of the coal extends from the northwest corner of sec. 13, T. 7 N., R. $27 \mathrm{~W}$., westward to the center of the south side of sec. 34, T. 8 N., R. 28 W., thence northward and eastward to the center of sec. 23, T. 8 N., R. 27 W. The area between these two lines of outcrop is underlain by the Charleston coal, but the coal has not been found farther east, although beds at the horizon at which it should occur are present. Throughout this area 4 to 23 inches of coal has been recorded in 26 measured sections and drill holes. In 18 of these records the coal is 14 to 20 inches 
thick, and the remaining sections, in which the coal is either thicker or thinner, are scattered and appear to represent only local features. The coal has been removed from about one-fourth of a square mile in five strip mines operated near the outcrop around the west end of this basin by the W. E. B. Coal Co. Seven small wagon mines have also operated on this coal in secs. 3,10 , and 11, T. 7 N., R. $27 \mathrm{~W}$. In the future some coal may be removed from this area by slope mines or by strip mines located near the outcrop of the coal bed.

Paris coal.-The Paris coal is present in three areas in the western part of the Arkansas coal field. (See pl. 35.) Two of these areas lie about 3 miles south of Charleston, are practically continuous, and constitute a total area of about $3 \frac{1}{2}$ square miles that is underlain by the Paris coal. The coal ranges from 14 to 22 inches in thickness in these two areas and averages about 18 inches. It bas been worked in 11 small strip mines and 1 small slope mine in these two areas. If the thickness of 18 inches of this coal is relatively uniform under the two areas, this coal may possibly be mined commercially in the future.

The largest area of occurrence of the Paris coal is in the Paris Basin, which lies north and west of Paris and covers a total area of about 14 square miles. Throughout most of the Paris Basin the thickness of the coal is 18 to 20 inches and is remarkably uniform. In the northwestern part of the basin, however, the thickness of the coal averages about 22 inches and is locally as great as 34 inches. The coal is also reported to have been more than 20 inches thick in the area mined out by the Grand No. 1 mine, in the extreme southeast point of the basin. The coal has been removed beneath about $3 \frac{1 / 2}{2}$ square miles of the total area of this basin, and 37 mines were operating or prepared to operate in the basin in 1934 . In addition to the operating mines, there are 38 abandoned mines in this basin. Eventually all or nearly all of the coal in this basin will probably be mined commercially.

Other coals.-Numerous thin coal beds are present in the western part of the Arkansas coal field, and locally coals as much as 18 inches thick have been recorded in drill holes. Coal 16 inches thick and about midway between the Lower Hartshorne and Charleston coals has been reported at three places. One place is in a diamond-drill hole in sec. 7, T. 7. N., R. $30 \mathrm{~W}$., one in the abandoned Sullivant wagon mine in sec. 13, T. 9. N., R. 31 W., and the third in the bed of the Arkansas River at Moores Rock, in sec. 13, T. 8 N., R. 30 W., where the coal has been dug for local use at times of low water. The coal at these three places is at or near the same horizon. This coal may be thicker at other points, and possibly it may be mined at least locally in the future. In the extreme southwest corner of the area the Cavanal coal has been mined at one place for local use.

It is unlikely that any other coal beds in the area are sufficiently thick at any point to be mined even locally. 
RANK, QUALITY, AND USES OF THE COAL,

All the coal in the western part of the Arkansas coal field is of lowvolatile bituminous rank. (See table of analyses.) It is low in content of volatile constituents, high in fixed carbon, and high in heating value as compared with coal of other ranks. In general it is very friable and must be handled carefully both in mining and transporting, in order to avoid shattering and excessive production of slack coal.

Most of the coal mined in the western part of the Arkansas coal field contains either a low or moderate amount of ash-forming materials. Practically all the coal mined in the area is used as domestic and steam-producing coal, uses for which it is well suited because of its high heating value and relatively low content of ash-forming materials.

\section{MINING METHODS}

Coal is mined commercially in the western part of the Arkansas coal field both in large strip mines and in underground mines. The strip mines are confined to the Charleston Basin and the west end of the Paris Basin, and all operate on the Charleston coal. The underground mines operating on the Lower Hartshorne coal are both slope and shaft mines, most of which operate on the double-entry roomand-pillar method. However, a few mines have used a modified long-wall system of mining on the Lower Hartshorne bed. In most of the mines operating on the Lower Hartshorne coal undercutting machines and middle-band cutters are used, but in a few mines the coal is shot from the solid face or undercut by hand. The Lower Hartshorne coal is hand-loaded in all mines. The mines operating in the Paris coal are both slope and shaft mines in which the advancing long-wall system is used. In all the large mines operating on the Paris coal undercutting machines are used together with loading machines of the scow-pan and conveyor-belt types. 
[Analyses by H. M. Cooper, U. S. Bureau of Mines]

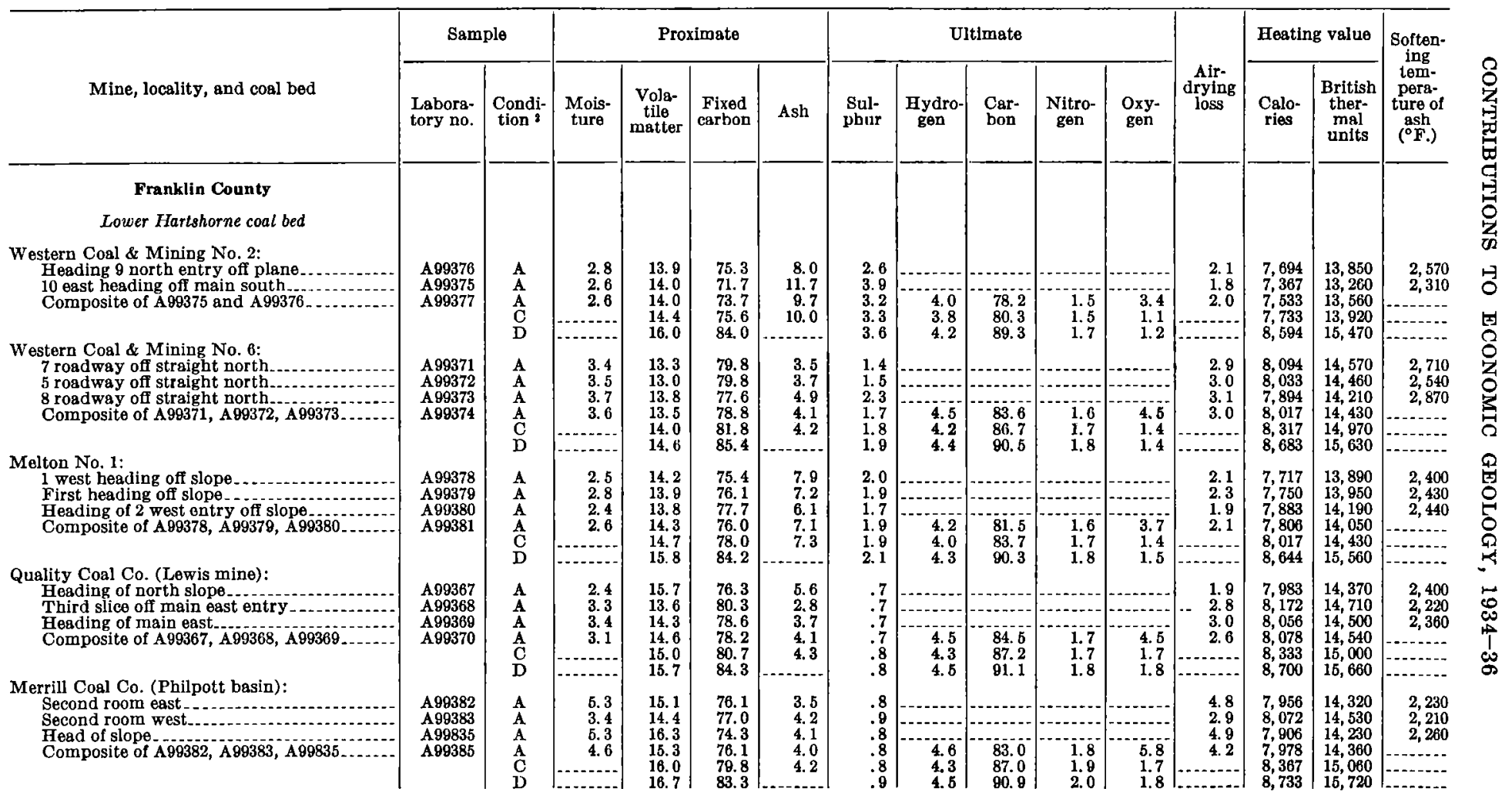


Johneon County

Lower Hartshorne coal bed

Sterling Coal Co.:

Heading $\theta$ west off main slope

Room 23 off 9 west off main slope

Room 21 off 10 west of main slope

Composite of A99386, A99387, A99388.--

McAlester Fuel Co. (Fernwood No. 2):

7 west heading off west slope

4 west heading off west slope

Composite of A99394, A99395, A99396

Clark \& McWilliams Coal Co.:

Heading 6 east entry off slope.

Heading 6 west entry off slope-

Composite of A99390, A99391, A 99392

\section{Logan County}

Lower Hartshorne coal bed

New Deal Coal Co. (Scranton):

3 west off old slope, room 1 .
3 west off old slope, room 8 .

3 west off old slope, room 8

Composite of A99831, A99832, A9982

\section{Paris coal bed}

Eureka Coal \& Mining Co.: 3

Face longwall 5 west off main slope

Face longwall 5 east off main slope.

Face longwall 6 east of main slope-
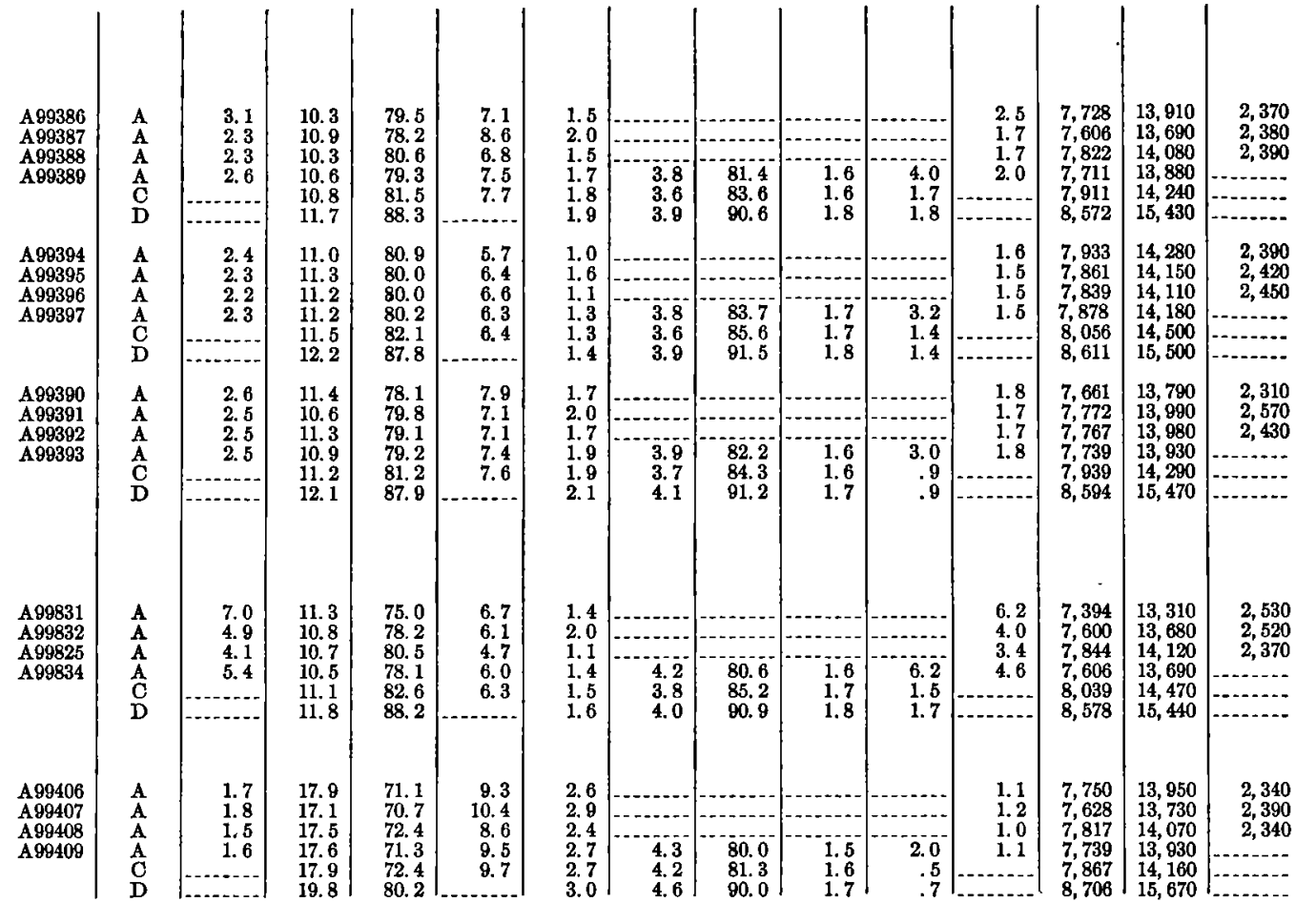

1 For additional analyses of Arkansas coals see Fieldner, A. C., Cooper, H. M., and Osgood, F. D., Analyses of Arkansas coals: U. S. Bur. Mines Tech. Paper 416, 1928, and Price, L. C., A study of Arkansas coals: Arkansas Univ. Bull., vol. 22, no. 13

a Mines in the western portion of the Arkansas coal field (locations given on pl. 35). 
[Analyses by H. M. Cooper, U. S. Bureau of Mines]

\begin{tabular}{|c|c|c|c|c|c|c|c|c|c|c|c|c|c|c|c|}
\hline \multirow[b]{2}{*}{ Mine, locality, and coal bed } & \multicolumn{2}{|c|}{ Sample } & \multicolumn{4}{|c|}{ Proximate } & \multicolumn{5}{|c|}{ Ultimate } & \multirow{2}{*}{$\begin{array}{c}\text { Air- } \\
\text { drying } \\
\text { loss }\end{array}$} & \multicolumn{2}{|c|}{ Heating value } & \multirow{2}{*}{$\begin{array}{l}\text { Soften- } \\
\text { ing } \\
\text { tem- } \\
\text { pers- } \\
\text { ture of } \\
\text { ash } \\
\left(^{\circ} \mathrm{F} .\right)\end{array}$} \\
\hline & $\begin{array}{l}\text { Labora- } \\
\text { tory no. }\end{array}$ & $\begin{array}{c}\text { Condi- } \\
\text { tion }\end{array}$ & $\begin{array}{c}\text { Mois- } \\
\text { ture }\end{array}$ & $\begin{array}{c}\text { Vola- } \\
\text { tile } \\
\text { matter }\end{array}$ & $\begin{array}{c}\text { Fixed } \\
\text { carbon }\end{array}$ & Ash & $\begin{array}{l}\text { Sul- } \\
\text { phur }\end{array}$ & $\underset{\text { gen }}{\text { Hydro- }}$ & $\begin{array}{l}\text { Car- } \\
\text { bon }\end{array}$ & $\begin{array}{c}\text { Nitro- } \\
\text { gen }\end{array}$ & $\begin{array}{l}\text { Oxy- } \\
\text { gen }\end{array}$ & & $\begin{array}{l}\text { Calo- } \\
\text { ries }\end{array}$ & $\begin{array}{c}\text { British } \\
\text { ther- } \\
\text { mal } \\
\text { units }\end{array}$ & \\
\hline \multicolumn{16}{|l|}{ Logan County-Continued } \\
\hline $\begin{array}{l}\text { Jewel Mining Co.: }{ }^{3} \\
\text { Face longwall } 1 \text { north off slope. } \\
\text { Face longwall } 1 \text { south off slope } \\
\text { Composite of A99824, A99833 }\end{array}$ & $\begin{array}{l}\text { A99833 } \\
\text { A99824 } \\
\text { A99826 }\end{array}$ & $\begin{array}{l}\mathbf{A} \\
\mathbf{A} \\
\mathbf{A} \\
\mathbf{C} \\
\mathbf{D}\end{array}$ & $\begin{array}{r}1.9 \\
2.5 \\
2.2 \\
\hdashline-1-2\end{array}$ & $\begin{array}{l}16.5 \\
16.7 \\
16.6 \\
16.9 \\
18.7\end{array}$ & $\begin{array}{l}73.5 \\
70.9 \\
72.0 \\
73.7 \\
81.3\end{array}$ & \begin{tabular}{l|}
8.1 \\
9.9 \\
9.2 \\
9.4
\end{tabular} & $\begin{array}{l}2.0 \\
2.5 \\
2.1 \\
2.2 \\
2.4\end{array}$ & $\begin{array}{l}4.5 \\
4.3 \\
4.7\end{array}$ & $\begin{array}{l}79.9 \\
81.7 \\
90.2\end{array}$ & $\begin{array}{l}1.6 \\
1.6 \\
1.8\end{array}$ & $\begin{array}{r}2.7 \\
.8 \\
.9\end{array}$ & \begin{tabular}{r|}
1.4 \\
2.0 \\
1.7 \\
\hdashline.--
\end{tabular} & $\begin{array}{l}7,850 \\
7,628 \\
7,739 \\
7,911 \\
8,728\end{array}$ & $\begin{array}{l}14,130 \\
13,730 \\
13,930 \\
14,240 \\
15,710\end{array}$ & $\begin{array}{r}2,360 \\
2,280 \\
\hdashline--\end{array}$ \\
\hline $\begin{array}{l}\text { Face longwall } 2 \text { east off main slope } \\
\text { Face longwall } 1 \text { east oft main slope } \\
\text { Face longwall } 2 \text { west off main slope } \\
\text { Composite of A99828, A99829, A99384 } \\
\text { Pope County }\end{array}$ & $\begin{array}{l}\text { A99828 } \\
\text { A99829 } \\
\text { A99384 } \\
\text { A99830 }\end{array}$ & $\begin{array}{l}\mathbf{A} \\
\mathbf{A} \\
\mathbf{A} \\
\mathbf{A} \\
\mathbf{C} \\
\mathbf{D}\end{array}$ & \begin{tabular}{l}
1.6 \\
1.8 \\
2.0 \\
1.8 \\
\hdashline-1
\end{tabular} & $\begin{array}{l}18.6 \\
17.7 \\
18.2 \\
18.2 \\
18.5 \\
20.3\end{array}$ & $\begin{array}{l}71.4 \\
70.9 \\
71.3 \\
71.1 \\
72.5 \\
79.7\end{array}$ & \begin{tabular}{l|}
8.4 \\
9.6 \\
8.5 \\
8.9 \\
9.0
\end{tabular} & $\begin{array}{l}2.4 \\
3.1 \\
2.3 \\
2.4 \\
2.5 \\
2.7\end{array}$ & $\begin{array}{l}4.4 \\
4.2 \\
4.7\end{array}$ & $\begin{array}{l}80.6 \\
82.0 \\
90.1\end{array}$ & $\begin{array}{l}1.6 \\
1.6 \\
1.8\end{array}$ & $\begin{array}{r}2.1 \\
.7 \\
.7\end{array}$ & \begin{tabular}{r|}
1.0 \\
1.3 \\
1.5 \\
1.3 \\
\hdashline$-1 .-$
\end{tabular} & $\begin{array}{l}7,833 \\
7,722 \\
7,817 \\
7,772 \\
7,911 \\
8,700\end{array}$ & $\begin{array}{l}14,100 \\
13,960 \\
14,070 \\
13,990 \\
14,240 \\
15,660\end{array}$ & $\begin{array}{r}2,370 \\
2,370 \\
2,390 \\
\hdashline-.-\end{array}$ \\
\hline Lower Hartshorne coal bed & & & & & & & & & & & & & & & \\
\hline $\begin{array}{l}\text { McA lester Fuel Co. (Bernice No. 3): } \\
4 \text { panel of } 6 \text { west off main slope- } \\
4 \text { panel of } 7 \text { west off main slope } \\
2 \text { panel of } 9 \text { east of main slope } \\
\text { Composite of A99410, A99411, A99412 }\end{array}$ & $\begin{array}{l}\text { A99410 } \\
\text { A99411 } \\
\text { A99412 } \\
\text { A99413 }\end{array}$ & $\begin{array}{l}\mathbf{A} \\
\mathbf{A} \\
\mathbf{A} \\
\mathbf{A}\end{array}$ & $\begin{array}{l}2.5 \\
2.9 \\
2.6 \\
2.7\end{array}$ & $\begin{array}{l}11.3 \\
10.7 \\
10.7 \\
10.9\end{array}$ & $\begin{array}{l}77.4 \\
77.7 \\
77.6 \\
77.6 \\
79.7\end{array}$ & $\begin{array}{l}8.8 \\
8.7 \\
9.1 \\
8.8\end{array}$ & $\begin{array}{l}1.7 \\
1.8 \\
2.2 \\
2.0 \\
2.0\end{array}$ & 3.7 & 80.7 & 1.5 & $\begin{array}{l}3.3 \\
8\end{array}$ & $\begin{array}{l}1.7 \\
2.0 \\
1.5 \\
1.7\end{array}$ & $\begin{array}{l}7,589 \\
7,544 \\
7,561 \\
7,556 \\
7\end{array}$ & $\begin{array}{l}13,660 \\
13,580 \\
13,610 \\
13,600 \\
13,080\end{array}$ & $\begin{array}{l}2,450 \\
2,360 \\
2,330 \\
-\cdots\end{array}$ \\
\hline Sebastian County & & D & |--- & 12.4 & $\begin{array}{l}79.7 \\
87.6\end{array}$ & & $\begin{array}{l}2.0 \\
2.2\end{array}$ & $\begin{array}{l}3.5 \\
3.9\end{array}$ & $\begin{array}{l}83.0 \\
91.3\end{array}$ & $\begin{array}{l}1.6 \\
1.7\end{array}$ & $\begin{array}{l}.8 \\
.0\end{array}$ & & $\begin{array}{l}7,767 \\
8,544\end{array}$ & $\begin{array}{l}13,980 \\
15,380\end{array}$ & - \\
\hline Lower Ilartshorne coal bed & & & & & & & & & & & & & & & \\
\hline $\begin{array}{l}\text { Majestic Coal Co.: } \\
\text { Heading } 7 \text { south off main west. } \\
\text { Heading } 7 \text { north off main west. } \\
\text { Heading } 3 \text { north off main west } \\
\text { Composite of } A 99402, A 99403, \text { A99404... }\end{array}$ & $\begin{array}{l}\text { A99402 } \\
\text { A99403 } \\
\text { A99404 } \\
\text { A99405 }\end{array}$ & $\begin{array}{l}\mathbf{A} \\
\mathbf{A} \\
\mathbf{A} \\
\mathbf{A} \\
\mathbf{C} \\
\mathbf{D}\end{array}$ & $\begin{array}{r}3.5 \\
3.3 \\
3.4 \\
3.4 \\
\hdashline-. . . \\
\hdashline-. . .\end{array}$ & $\begin{array}{l}16.2 \\
16.6 \\
16.5 \\
16.2 \\
16.7 \\
18.4\end{array}$ & $\begin{array}{l}72.1 \\
70.7 \\
71.9 \\
71.8 \\
74.4 \\
\mathbf{8 1 . 6}\end{array}$ & \begin{tabular}{l|}
8.2 \\
9.4 \\
8.2 \\
8.6 \\
8.9
\end{tabular} & $\begin{array}{l}.9 \\
1.0 \\
.8 \\
1.0 \\
1.0 \\
1.1\end{array}$ & $\begin{array}{l}4.3 \\
4.1 \\
4.5\end{array}$ & $\begin{array}{l}79.6 \\
82.4 \\
03.5\end{array}$ & $\begin{array}{l}1.7 \\
1.8 \\
2.0\end{array}$ & $\begin{array}{l}4.8 \\
1.8 \\
1.9\end{array}$ & \begin{tabular}{l}
2.8 \\
2.5 \\
2.8 \\
2.7 \\
\hdashline.- \\
..-
\end{tabular} & $\begin{array}{l}7,633 \\
7,561 \\
7,639 \\
7,611 \\
7,878 \\
8,656\end{array}$ & $\begin{array}{l}13,740 \\
13,610 \\
13,750 \\
13,700 \\
14,180 \\
15,580\end{array}$ & \begin{tabular}{r}
2,090 \\
2,090 \\
2,140 \\
\hdashline \\
\end{tabular} \\
\hline
\end{tabular}




\begin{tabular}{|c|c|c|c|c|c|c|c|c|c|c|c|c|c|c|c|}
\hline \multirow{6}{*}{$\begin{array}{l}\text { Excelsior Producer Coal Co. (Bianca): } \\
\text { Heading } 2 \text { north entry } \\
\text { Heading } 1 \text { north entry } \\
\text { Heading } 2 \text { south entry } \\
\text { Composite of A99414, A99415, A99416..... }\end{array}$} & \multirow{6}{*}{$\begin{array}{l}\text { A99414 } \\
\text { A99415 } \\
\text { A99416 } \\
\text { A99417 }\end{array}$} & \multirow{7}{*}{$\begin{array}{l}\mathbf{A} \\
\mathbf{A} \\
\mathbf{A} \\
\mathbf{A} \\
\mathbf{C} \\
\mathbf{D}\end{array}$} & \multirow{6}{*}{$\begin{array}{l}7.0 \\
4.4 \\
5.7 \\
5.7\end{array}$} & \multirow{7}{*}{$\begin{array}{l}15.2 \\
16.5 \\
15.5 \\
15.5 \\
16.5 \\
17.3\end{array}$} & \multirow{7}{*}{$\begin{array}{l}72.6 \\
73.7 \\
73.5 \\
73.3 \\
77.7 \\
82.5\end{array}$} & \multirow{6}{*}{$\begin{array}{l}5.2 \\
5.4 \\
5.3 \\
5.5 \\
5.8\end{array}$} & \multirow{4}{*}{$\begin{array}{l}1.2 \\
1.3 \\
1.8\end{array}$} & & & & \multirow{6}{*}{$\begin{array}{l}6.4 \\
3.8 \\
5.1 \\
5.1\end{array}$} & \multirow{7}{*}{$\begin{array}{l}7,622 \\
7,850 \\
7,711 \\
7,739 \\
8,206 \\
8,711\end{array}$} & \multirow{7}{*}{$\begin{array}{l}13,720 \\
14,130 \\
13,880 \\
13,930 \\
14,770 \\
15,680\end{array}$} & \multirow{4}{*}{$\begin{array}{l}2,360 \\
2,180 \\
2,340\end{array}$} \\
\hline & & & & & & & & & & & & & & & \\
\hline & & & & & & & & & & & & & & & \\
\hline & & & & & & & & & & & & & & & \\
\hline & & & & & & & 1.5 & 4.7 & 80.1 & 1.7 & 6.5 & & & & \\
\hline & & & & & & & & 4. 3 & 85.0 & 1.8 & 1.6 & & & & $-\cdots-1$ \\
\hline \multicolumn{11}{|l|}{ Excelsior Coal Co., Inc. (Skinner mine): } & & & & & \\
\hline Heading 6 west entry & A99827 & A & 4.9 & 15.7 & 77.0 & 2.4 & .7 & & & & & 4.3 & 8,061 & 14 & 2,230 \\
\hline 1 west wall off 6 west entry & A99836 & $\mathbf{A}$ & 2.9 & 16. & 77.3 & 3. 2 & .7 & & & & & 2.4 & & & 2,210 \\
\hline Face of 6 east entry & A99837 & $\mathbf{A}$ & 3. 8 & 16. 4 & 76 & 3. 0 & .7 & & & & & & & & 2,160 \\
\hline Composite of A99827, A99836, A99837. & A99838 & $\mathbf{A}$ & 3. 9 & 16 & 77. & 3. 0 & .6 & 4.7 & 84. 3 & 1.8 & 5.6 & 3.3 & 8,117 & 14,610 & \\
\hline & & C & & & 80. & 3. 1 & .7 & 4.5 & 87.6 & 1.9 & 2. 2 & & 8,439 & 15,190 & - \\
\hline \multicolumn{16}{|l|}{$\begin{array}{l}\text { Barr Coal Co.: } 3 \\
\text { Room } 7 \text { off } 2 \text { west entry }\end{array}$} \\
\hline Room 7 off 2 west entry... & A99418 & A & 4.1 & 15.4 & 75 & 5.1 & 1.1 & & & & & 3.3 & 7,867 & 14,160 & 2,370 \\
\hline Room 5 off 2 wast $\theta$ & A99419 & & & 75 & & 5 & 1. & &. & & & & & & 2,370 \\
\hline Roo & 420 & & 4. 1 & 15. & 75.8 & 4.7 & 1.0 & & & & & 3.4 & 7,933 & & 2,340 \\
\hline Composite of A99418, A99419, A99420. & A99421 & A & 3.8 & 15.5 & 75.7 & 5. 0 & 1.1 & 4.7 & 82. 2 & 1.8 & 5. 2 & 3. 1 & 7,917 & 14,250 & $\cdots$ \\
\hline & & D & & 17 & 8 & & 1. 2 & $\begin{array}{l}4.4 \\
4.7\end{array}$ & $\begin{array}{l}80.2 \\
90.2\end{array}$ & 2.0 & 1.9 & & $\begin{array}{l}8,250 \\
8,683\end{array}$ & $\begin{array}{l}14,820 \\
15,630\end{array}$ & \\
\hline \multirow{6}{*}{$\begin{array}{l}\text { R. A. Young \& Son Coal Co. (Western No. 18): } \\
\text { Head of D entry off main slope } \\
\text { Head of } 6 \text { north off main slope- } \\
\text { Head of } 5 \text { north off main slope- } \\
\text { Composite of A99398, A9939, A99400 }\end{array}$} & & & & & & & & & & & & & & & \\
\hline & A99398 & $A$ & 1.7 & 15.4 & 76.7 & 6. 2 & 1.0 & & & & & 1.2 & 7 & & 2,400 \\
\hline & A99399 & A & 2.1 & 14.7 & 77.5 & 5. & 1.0 & & & & & 1.6 & & & 2,420 \\
\hline & A99400 & $\mathrm{A}$ & 2. 2 & 14. 0 & 76.8 & 7.0 & 1. 2 & 43 & & & & 1.7 & 7,856 & 14,140 & 2,300 \\
\hline & A89401 & & & 1 & 78 & 6.4 & 1.1 & $\begin{array}{l}4.5 \\
4.1\end{array}$ & $\begin{array}{l}80.0 \\
84.8\end{array}$ & 1.7 & 1. 9 & & & 14,590 & (n) \\
\hline & & & & 16.2 & & & 1.2 & 4. & 90.6 & 1.8 & 2. 0 & & & 15,590 & \\
\hline
\end{tabular}

${ }^{3}$ Mines in the western portion of the Arkansas coal feld (locations given on pl. 35). 


\section{NATURAL GAS}

\section{OCCURRFNCE}

Natural gas was discovered in Arkansas in March 1902, when the Choctaw Oil Co. No. 2 well, at the northeast corner of lot 7, sec. 1, T. 4 N., R. 31 W., in the Mansfield gas field, blew in with an original volume of 550,000 cubic feet. Since that time seven other fields have been discovered in the western part of the Arkansas coal field, and producing areas have been discovered in other parts of the State. In addition to the producing fields, many exploratory wells have been drilled that have yielded only shows of gas. Most of the unproductive wells, however, have been located at points where the geologic structure is unfavorable for the accumulation of gas or were not drilled to sufficient depth to reach beds known to carry gas in other parts of the area. Several areas in the western part of the Arkansas coal field in which the geologic structure is favorable for the accumulation of gas have not been adequately tested.

The gas-producing areas of the western part of the Arkansas coal field are the Alma, Shibley, Kibler-Williams, Massard Prairie, Lavaca, Vesta, Etna, and Mansfield gas fields. Condensed well data for those fields are given in the table below.

Well data for gas fields in the western part of the Arkansas coal field, compiled in part from data obtained from field work and in part from data supplied by operating gas companies

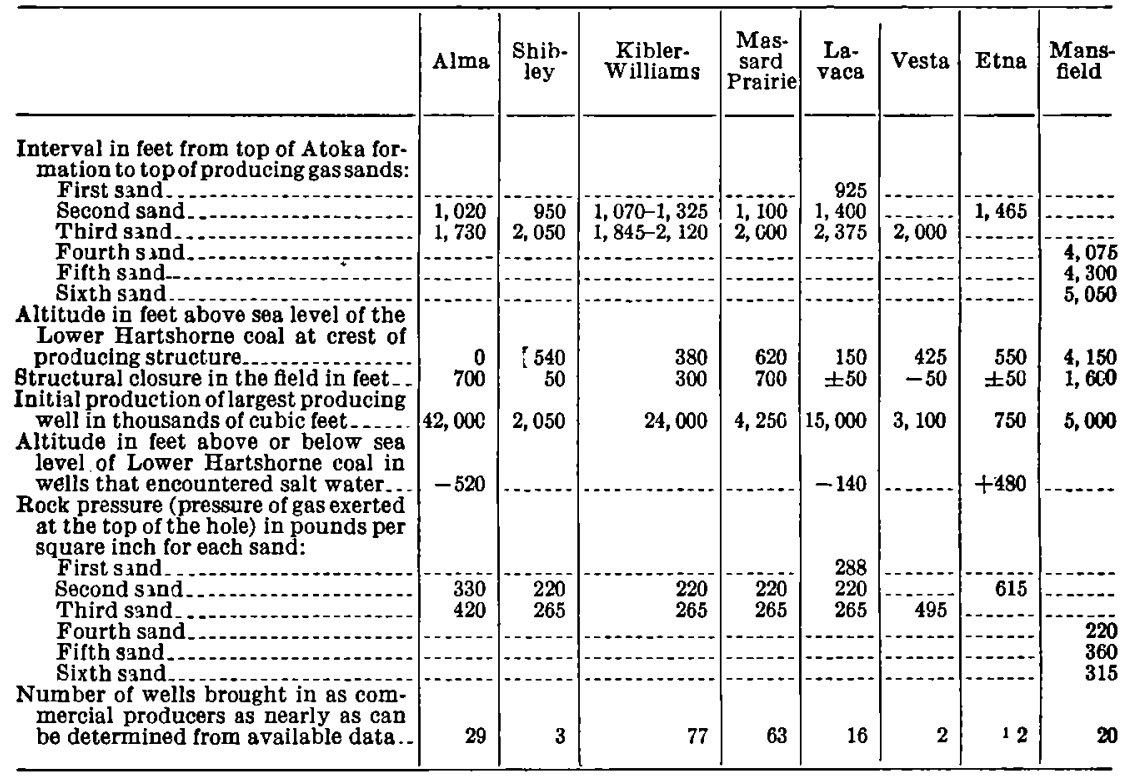

I Small producers. 
All the gas produced commercially in the western part of the Arkansas coal field has come from sandstones in the Atoka formation, although small amounts of gas have been obtained in shale of the Atoka formation in a few wells. In the Massard Prairie, KiblerWilliams, Shibley, and Alma gas fields two sands are productive. The upper one is a sandstone or group of sandstones about 250 feet thick that lies between 950 and 1,325 feet below the top of the Atoka formation. The lower one is a sandstone 40 to 200 feet thick that lies 1,730 to 2,120 feet below the top of the Atoka formation. The sands at both horizons, as well as one about 500 feet above the upper sand, are productive in the Lavaca field. In the Vesta field, only the lower sand is productive, but a flow of about 100,000 cubic feet came from a sand about 100 feet below the upper sand. In the Etna field the upper sand is the only one for which production is recorded. In general the lower sand is the more productive, but in a few wells the upper sand yields more than the lower. The two general horizons marked by sands are undoubtedly continuous over the northern part of the area, but it is unlikely that any single sandstone at either of these horizons is continuous.

In each of these fields the relation between the structural altitude and relative amount of production of the different wells is very irregular. Large producers are as common on the flank of an anticline as on the crest. This relation indicates that the accumulation of gas is controlled partly by structural altitude and partly by the porosity of the gas-bearing sand. Except in the Vesta and Alma fields; the producing wells in the area in general have a low rock pressure, rather low initial production, and a relatively long life. These features indicate that the gas migrates slowly in the producing sands, probably because of the low pressure and low porosity. The producing sands probably contain considerable amounts of silt or clay that reduce the effective porosity, for it is reported that "shooting" the sands with nitroglycerine has not appreciably increased the flow in the wells and in some wells has even decreased the initial flow. This suggests that clay or silt in the sand was packed by the force of the shot and the porosity thus reduced. If clay and silt were not present in the sand the rock would shatter and additional conduits would be opened, thus increasing the flow of gas into the well. In the greater part of the area wells drilled even near synclinal axes have yielded small amounts of gas, and, according to available records, salt water has been encountered at only a few places in the area. The absence of salt water in the synclines in most of the area explains the presence of at least small quantities of gas in the synclines, and the lack of hydrostatic pressure exerted on the gas by salt water is in part responsible for the relatively low pressure and initial flow. 
In the Alma gas field, salt water was encountered in a well in which the Lower Hartshorne coal is about 520 feet below sea level. The salt water rose 871 feet in the well because of hydrostatic pressure. That pressure is also exerted on the gas in the producing area of the Alma field and accounts for the high rock pressure in that field. The high pressure in turn accounts for the high initial flow of the wells. Eventually, as more gas is produced in the Alma field, wells that are successively higher structurally will cease to yield gas and begin to show salt water in the bottom of the hole.

Salt water was encountered at several horizons in a well near the axis of the Central syncline in sec. 34, T. 8 N., R. 30 W. The Lower Hartshorne coal lies about 140 feet below sea level in that well. About 6 miles farther southeast, salt water was encountered in a well at about the same structural altitude, on the north flank of the Greenwood syucline in sec. 28 , T. 8 N., R. 29 W.

Salt water was encountered in a well at a structural altitude of about 480 feet on the north side of the Etna anticline. No other wells have recorded salt water, and as the water was encountered over a range of 1,000 feet in structural altitude it is impossible to predict the level of salt water in other areas.

\section{PRODUCTYON}

Available statistics of production are inadequate to determine the total production of gas in the western part of the Arkansas coal field since 1904, but it is probable that between 250 and 300 billion cubic feet of gas has been produced. Gas production and reserves in producing fields were considered at length by Croneis ${ }^{12}$ in a report on the geology of the Arkansas Paleozoic area prepared for the Arkansas Geological Survey in 1927 and are not duplicated here.

\section{NATURE OF· THE GAS}

The gas produced in the western part of the Arkansas coal field is of high quality. It is high in methane $\left(\mathrm{CH}_{4}\right)$, and only a few samples contain ethane $\left(\mathrm{C}_{2} \mathrm{H}_{6}\right)$. It contains small amounts of carbon dioxide, oxygen, and nitrogen.

\section{Analyses of Arkansas natural gas 1}

[U. S. Bureau of Mines, analyst]

\begin{tabular}{|c|c|c|c|c|c|}
\hline & Methane & Ethane & $\begin{array}{l}\text { Carbon } \\
\text { dioxide }\end{array}$ & Oxygen & Nitrogen \\
\hline $\begin{array}{r}\text { Massard Prairio } \\
\text { Kibler-Williams. } \\
\text { Do } \\
\text { Do } \\
\text { Do } \\
\text { Do } \\
\text { Do } \\
\text { Do }\end{array}$ & $\begin{array}{l}97.96 \\
98.21 \\
98.03 \\
93.20 \\
95.30 \\
98.03 \\
98.21\end{array}$ & $\begin{array}{l}\text { None } \\
\text { None } \\
\text { None } \\
4.31 \\
1.74 \\
\text { None } \\
\text { None }\end{array}$ & $\begin{array}{r}\text { None } \\
0.08 \\
.33 \\
.32 \\
.33 \\
.33 \\
.08\end{array}$ & $\begin{array}{r}1.55 \\
.92 \\
.83 \\
.32 \\
.41 \\
.83 \\
.92\end{array}$ & $\begin{array}{r}0.32 \\
.62 \\
.66 \\
1.75 \\
2.07 \\
.66 \\
.62\end{array}$ \\
\hline
\end{tabular}

1 After Croneis, Carey, op. cit., p. 371.

12 Croneis, Carey, Geology of the Arkansas Paleozoic area: Arkansas Geol. Survey Bull. 3, pp. 368-440, 1927. 


\section{GAS FIELDS}

\section{MANSFIELD GAS FIELD}

The Mansfield gas field was discovered in 1902, when the Duncan No. 2 well of the Choctaw Oil \& Gas Co. was brought in with an original production of 550,000 cubic feet. It is reported that 32 wells have been drilled in this field, but the field party working under the direction of the writer could find the locations of only 28 wells. Of the wells located, 8 were either dry holes or produced so little gas as to be of no commercial importance. The remaining 20 wells have produced gas in commercial quantities, and most of them are still potential producers.

A study of the available drillers' logs of wells in the Mansfield gas field indicates that the commercial production comes from sands at three horizons $-4,075,4,300$, and 5,050 feet below the top of the Atoka formation. Each of these sands appears to be highly variable in both thickness and character, ranging from 200 feet of hard sandstone to mostly sandy shale with about 40 feet of sandstone. The production comes from different levels in these sands in different wells and is probably controlled by the variations in the character of the sands. In most of the wells the production comes from sand at the uppermost horizon, which lies about 800 to 1,200 feet beneath the surface in the wells. In addition to the commercial production, shows of gas have been recorded at seven horizons in beds of shale or thin sandstone that lie above the first producing sand. It seems improbable, however, that commercial production may be expected from any of those beds. No attempt has been made to test sands below the lowest producing beds, and although no prediction can be made it is possible that additional producing beds might be discovered by deeper drilling in the proved area. A small but permanent yield of gas was obtained from a well in the $\mathrm{NW} / 4 / \mathrm{SW} 1 / 4$ sec. $3, \mathrm{~T} .4 \mathrm{~N}$, R. $31 \mathrm{~W}$., on the axis of the Hartford anticline, though about 500 feet lower structarally than the producing wells of the main gas field. A show of gas was also obtained in a well near the center of sec. 35, T. 5. N., R. 30 W., a short distance south of the axis of the anticline and about 1,000 feet lower structurally than the producing wells of the proved gas area. These wells suggest that the producing area may be extended southwestward and northeastward along the axis of the anticline. Three dry holes drilled no more than 150 feet below the crest of the anticline on the south flank indicate that extension of the field north or south of the axis seems improbable.

The wells in this field are small, the greatest production being $4,500,000$ cubic feet a day. The small production is compensated for, however, by the long life of the wells. Both these features are illustrated by the history of the discovery well, which was completed in March 1902 with an initial production of 550,000 cubic feet and a rock pressure of 220 pounds. Three years later the volume had 
increased to 915,000 cubic feet and the pressure to 305 pounds. Throughout the years since that time the well has been alternately closed in and turned back into the pipe line. During each period of production the volume and pressure decreased gradually, and during the periods when the well was shut in the volume and pressure increased gradually but not to the level of the preceding shut-in period.

\section{ETNA GAS FTELD}

The Etna gas field lies on the Etna anticline, which extends northeastward across T. 8 N., R. 28 W., and eastward across T. 8 N., Rs. 27 and $26 \mathrm{~W}$. Six wells have been drilled on the Etna anticline in secs. 14,15 , and 16, T. 8 N., R. 27 W., and the two wells nearest the axis of the anticline have yielded a small production from a sand about 1,465 feet below the top of the Atoka formation. Wells no more than 50 feet lower structurally have yielded salt water, however, and production may be expected only on the axis of the anticline or very near it. The anticline plunges slightly to the west, and only slight production might be expected west of the well in the $\mathrm{SE} / 4 \mathrm{NE} / 4$ sec. 16, T. 8 N., R. 27 W. Eastward, however, the anticline rises slightly, and small production might be expected in wells on or very near the axis of the anticline as far east as the Arkansas River. Some gas also may be present on the north side of the Etna fault in the N $1 / 2$ secs. 1, 2, 3, 4, and 5, T. 8 N., R. 27 W.

\section{VESTA GAS FIELD}

Two producing gas wells have been drilled in sec. 24 , T. 8 N., R. $29 \mathrm{~W}$., near Vesta. These wells are on a terrace on the south flank of the Cecil anticline. In the one well of which records are available 100,000 cubic feet of gas was obtained in a sandstone about 50 feet thick, 1,500 feet below the top of the Atoka formation, and 3,100,000 cubic feet in a sandstone about 80 feet thick, 2,000 feet below the top of the Atoka formation. The initial rock pressure was 495 pounds. Exposures in that area are poor, and it is impossible to determine the extent of the fold in which the gas has accumulated. Possibly, however, the fold may continue eastward from the wells already drilled.

\section{IATACA GAS FIELD}

The Lavaca gas field is in secs. $21,22,27,28$, and 29, T. 8 N., R. $30 \mathrm{~W}$. Sixteen producing wells have been drilled in this field, and one dry hole has been drilled in the Central syncline just south of the field. Sands at three horizons have produced gas. Two wells have produced from a sandstone that lies about 925 feet below the top of the Atoka and is about 100 feet thick. All the other wells in the field have passed through this sand without yielding gas. Three wells have encountered a small flow of gas from a sand about 1,400 feet 
below the top of the Atoka and in the lower part of a sandstone about 250 feet thick. The major production in the field, however, comes from a sandstone 150 feet thick that lies about 2,375 feet below the top of the Atoka. No well has been drilled far enough beneath the main producing sand to test any possible producing sands lower in the Atoka formation. Other gas-bearing sands may lie lower in that formation and may be tested in the future. The production comes from the Lavaca anticline, which plunges westward at a low angle and has no structural closure that can be recognized from either surface exposures or well logs. Additional production may possibly be obtained along the axis of the anticline northeastward from the area that has already been tested. A study of the drillers' logs of the wells indicates that the wells in the $\mathrm{NW}^{1 / 4} \mathrm{NW}^{1 / 4}$ and the $\mathrm{NW}^{1 / 1} \mathrm{NE} / 4$ sec. 29 are separated from the remainder of the field by a fault that dropped the beds on the southeast side in relation to the beds on the northwest side. Gas may have accumulated on the north side of this fault from the well in the northwest corner of sec. 29 as far west as the Massard Prairie gas field.

\section{MASSARD PRAIRIE GAS FIELD}

The Massard Prairie gas field is in the northeast corner of T. 7 N., R. 32 W., the southeast corner of T. 8 N., R. 32 W., and the southwest corner of T. 8 N., R. $31 \mathrm{~W}$. The production in this field comes from sands of two horizons. The upper horizon is marked by a group of sandstones that lies about 1,100 feet below the top of the Atoka formation and is about 270 feet thick. Gas has been encountered throughout the group. Most of the wells in the field have stopped in or at: the base of this group of sandstones, and consequently most of the production in the field comes from these beds. The sand at the lower horizon is near the top of a sandstone about 200 feet thick that lies about 2,000 feet below the top of the Atoka formation. Small amounts of gas have been recorded in sandstones above the 1,100-foot sand but were not great enough to be of commercial importance. The producing wells have been drilled on the northwest side of the Massard Prairie fault, which closes the Massard Prairie anticline on the south side. Probably the field could be extended southwestward for about $1 \frac{1}{2}$ miles, and some production might be expected on the north side of the Massard Prairie fault as far east as the Lavaca gas field. Additional gas could be produced by drilling some of the wells that have produced from sands at the upper horizon down to the lower producing sand in the parts of the field where the lower sand has not been drained by old wells. Small producing wells in secs. 1 and 12, T. 8 N., R. 32 W., near the axis of the Fort Smith syncline, which lies north of the Massard Prairie anticline, indicate that some additional gas might be obtained by drilling north of the present producing area. 
The Shibley gas field is in secs. 15 and 22, T. 9 N., R. 32 W. Records are available for three producing wells, three small producers, and one well with a show of gas in this field. The production comes from sands at three horizons. The uppermost is a sandstone 150 to 200 feet thick that lies about 950 feet below the top of the Atoka formation. The second is a sandstone 50 to 150 feet thick with its top about 1,450 feet below the top of the Atoka formation, and the lowest is a. sandstone logged as only about 45 feet thick that lies about 2,050 feet below the top of the Atoka formation. The production has come from a small area of structural closure on the Shibley anticline, and it is improbable that the field can be extended very much in any direction.

\section{ALMA GAS FIELD}

The Alma gas field is in the northwest corner of T. 9 N., R. 30 W. Production in this field comes from sands at two horizons. The upper one is a sandstone and sandy shale zone about 200 feet thick that lies about 1,020 feet below the top of the Atoka formation, and the lower one is a sandstone about 1,730 feet below the top of the Atoka formation. According to drillers' logs this lower sandstone ranges from 30 to 100 feet in thickness in the wells that penetrate it. The sands in strong producing wells have a structural range of about 450 feet, which is greater than that in any other field in the area covered by this report. The initial production from wells in this field was extremely high, the largest well being reported to have an initial flow of $42,000,000$ cubic feet. The original rock pressures were 330 pounds for the upper sand and 420 pounds for the lower and. Both the production and the pressure have declined rapidly in this field, and, although the total production will be great because of the high initial volume of the wells, the life of the field probably will be much shorter than that of other fields in the area considered in this report. Structurally, the field is closed on the north and west by the Mulberry and River Ridge faults. On the south it is closed by the southward dip of the beds into the Bectum Hill syncline. Salt water rose 871 feet in a well drilled into

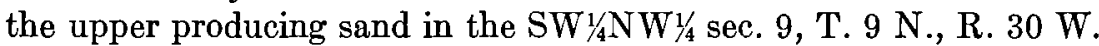
This salt-water table marks the southern limit of the field, and the hydrostatic head indicated by the rise of 871 feet in the hole probably accounts for the high pressure and high initial production in the field. The structural closure on the east side of the Alma gas field is not clearly marked. However, in a well drilled in the $\mathrm{SW} 1 / 4 \mathrm{NE}_{1}^{1 / 4}$ sec. 2, T. 9 N., R. 30 W., near Dyer, the beds are structurally more than 300 feet lower than in a well drilled about a quarter of a mile farther northeast in the same section. This difference suggests that a fault is present between those wells. The writer believes that the fault also lies south of a well drilled in the $\mathrm{SE} / 4 \mathrm{sec} .34, \mathrm{~T} .10 \mathrm{~N}$., R. $30 \mathrm{~W}$., joins the Alma fault somewhere near the west line of sec. 34 , and forms the structural closure on the east side of the Alma field. 


\section{KIBLER-WILIIAMS GAS FIELD}

The Kibler-Williams gas field lies in the southwest corner of T. 9 N., R. $30 \mathrm{~W}$, the northwest corner of T. $8 \mathrm{~N}$., R. $30 \mathrm{~W}$., the northeast corner of T. 8 N., R. 31 W., and the southeast corner of T. 9 N., R. $31 \mathrm{~W}$. The proved productive area in this field is about 15 square miles. The production in this field comes from sands at two horizons. The upper one is a sandstone or group of sandstones about 250 feet thick that lies between 1,070 and 1,325 feet below the top of the Atoka formation. The lower and more productive one is a sandstone 40 to 165 feet thick that lies 1,845 to 2,120 feet below the top of the Atoka formation. The producing area lies on the crest and flanks of the Kibler anticline, and the volume of gas yielded in each well is only roughly related to the structural altitude of the producing sands, as large producers lie near small producers, both on the flanks and on the crest. Possibly the field may be extended eastward for a short distance and westward for 3 or 4 miles in the southern part of T. 9 N., R. $31 \mathrm{~W}$. A well in the $\mathrm{SE}^{1 / 4} \mathrm{SW}^{1 / 4}$ sec. 33 of that township and outside the area of structural closure, which yielded 750,000 cubic feet of gas, lies only a short distance west of the area in which commercial production may be expected.

\section{LOCALTTIES STRUCTURALLY FAVORABLE FOR ACCUMULATION OF GAS}

\section{BISWELL HILL ANTICLINE}

The Biswell Hill anticline extends eastward from the southwest corner of sec. 27, T. 7 N., R. 31 W., to the northeast corner of sec. 29 , T. 7 N., R. 29 W. An area of structural closure about 8 square miles in extent is present on the anticline. The closure is about 200 feet and is structurally favorable for the accumulation of gas. Three wells have been drilled on this anticline, and all have yielded shows of gas. Two of the wells were drilled outside the area of structural closure, but one was high on the anticline in the $\mathrm{SW} / 1 / 4 \mathrm{SE} 1 / 4$ sec. $18, \mathrm{~T}$. 7 N., R. $30 \mathrm{~W}$., and was drilled to a depth of 2,504 feet. The failure of this well to yield more than a show of gas is discouraging but is not sufficient to condemn the anticline as a possible producing area. Wells drilled to a depth of about 2,700 feet near the center of the $\mathrm{NE}^{1 / 4}$ sec. 19 and near the center of the west side of sec. 22, T. 7 N., R. 30 W., should test the anticline adequately.

\section{VACHE GRASSE ANTICLINE}

The Vache Grasse anticline extends almost due eastward about 6 miles from the $\mathrm{SE}^{1 / 4}$ sec. 31 , T. 8 N., R. $31 \mathrm{~W}$. There is no structural closure on this anticline, but a small producing well was drilled in the $\mathrm{SE}_{1 / 4}^{1 / 4 e c}$. 34, T. 8 N., R. $31 \mathrm{~W}$, and possibly additional production might be obtained in wells drilled near the axis of the anticline as far west as the center of the $\mathrm{S} 1 \%$ sec. 32 . Test wells on this anticline should be drilled to a depth of at least 2,900 feet. 


\section{GAMB HIII ANTICLNR}

The Game Hill anticline extends eastward from sec. 3, T. 7 N., R. 30 W., to sec. 5 , T. 7 N., R. 27 W., where it ends against a fault. There are two areas of structural closure on this anticline. One is a roughly elliptical area of about 2 square miles that extends from the NE1/4 sec. 2 , T. 7 N., R. 30 W., to the SW $1 / 4$ sec. 32 , T. 8 N., R. 29 W., and has a closure of less than 100 feet. A well drilled to a depth of 3,235 feet in the center of this area of closure obtained about 250,000 cubic feet of gas at 2,558 feet. This well does not prove the entire area of structural closure to be nonproductive, although it does discourage additional drilling. The second area of structural closure covers about $5 \frac{1}{2}$ square miles, chiefly in secs. $1,2,3$, and $4, \mathrm{~T} .7 \mathrm{~N}$, R. $28 \mathrm{~W}$., and secs. 5 and 6, T. 7 N., R. $27 \mathrm{~W}$. The closure is about 150 feet. It is reported that a well was drilled to a depth of about 800 feet in the northern part of sec. 3, T. 7 N., R. 28 W., which is inside the area of closure. This well was not deep enough to be considered a test of the anticline, and possibly wells drilled near the axis of the anticline in the area of closure may yield gas. Possibly, however, the fault that forms the closure on the north side of the anticline may have served as an avenue of escape for any gas that may have been present in the anticline.

\section{CLOSORE AGAINST BER BLUFP FAULT}

An area of structural closure lies in the northwestern part of T. $9 \mathrm{~N}$., R. $27 \mathrm{~W}$., on the east side of the Bee Bluff fault and between the Ozark and River Ridge faults. As the exact position and trend of the Bee Bluff fault cannot be determined from surface outcrops, the western limit of this area of closure is indeterminate. About 2 miles east of this area of closure is a small dome, in secs. 14, 15, 22, and 23, T. 9 N., R. 27 W. Both these areas are structurally suited for trapping gas, but possibly the Bee Bluff fault may have served as an avenue of escape for any gas present. The Hartshorne sandstone caps the higher ground in both areas, and beds in the Atoka formation are present in the valleys. In order to test either of these areas for gas it would be necessary to drill about 2,700 feet beneath the surface of the higher ground capped by the Hartshorne sandstone.

\section{MANITOU ANTICLNB}

The Manitou anticline is a broad domelike fold that extends eastward for about 2 miles from the SE1/4 sec. 36, T. 10 N., R. 28 W., and thence southeastward to the Ozark fault in sec. 4, T. 9 N., R. 27 W. The structural closure on the anticline is about 140 feet, and the area of closure is about $7 \frac{1}{2}$ square miles. The Hartshorne sandstone caps the high tablelike hill in the central part of the anticline, and beds in the Atoka formation crop out at the surface over the remainder of the area. A well drilled to a depth of 1,980 feet in the $S W 1 / 4$ sec. 34, 
T. 10 N., R. 27 W., within the area of structural closure, was reported to be a dry hole, as was also a well drilled to a depth of 1,100 feet about a mile farther northeast, on the edge of the area of closure. The failure of the deeper of these two wells to yield gas is discouraging, but possibly some gas may be present in the structurally higher part of the anticline.

\section{GECII ANTHCLNR}

The Cecil anticline is a broad fold that extends from the Arkansas River in sec. 36, T. 9 N., R. 30 W., eastward to the River Ridge fault in sec. 20, T. 9 N., R. $27 \mathrm{~W}$. The structural closure on this anticline is about 200 feet and covers a large area. Four wells have been drilled on this anticline. One well, in sec. 27, T. 9 N., R. 28 W., was on the structurally highest part of the anticline. It is reported to have been drilled to a depth of 2,700 feet and to have obtained a small flow of gas. The failure of this well to produce more than a small quantity of gas is definitely unfavorable, but additional testing of the anticline would be justified on the basis of small production having been obtained in nearby fields in wells as favorably situated as large producers only a short distance away on the same fold. Small producing wells have been drilled structurally lower on the west end of this anticline in sec. 29 , T. 9 N., R. 29 W., and sec. 36 , T. 9 N., R. 30 W. A well reported to be a dry hole was drilled near the axis on the east end of the Cecil anticline in sec. 29, T. $9 \mathrm{~N}$., R. $27 \mathrm{~W}$. These three wells indicate that any gas that may be discovered on this anticline is likely to be in the structurally high part. Gas could be present on either side of the Cecil fault, which divides this anticline into two parts, and could be lacking on the opposite side. Failure to obtain production on one side of the Cecil fault would not condemn the other side until it also had been tested.

\section{CLOSURE AGAINST MIILL CREEK FAULT}

The Mill Creek fault lies south of the axis of the Cecil anticline and parallel to it. There is about 250 feet of structural closure against this fault. The presence of gas in the small terrace or anticline at Vesta, which lies immediately south of this area of closure and structurally lower, suggests that gas may have migrated up the northwardrising beds and may have been trapped in the area of structural closure south of the fault. Possibly also the fault may have served as an avenue of escape for northward-moving gas. This area can be tested only by drilling.

CLOSURE AGAINST MULBERRT FAULT IN T. $\theta$ N., R. 31 W.

A well drilled in the NE $1 / 4 \mathrm{NW}^{1 / 4}$ sec. $15, \mathrm{~T} .9 \mathrm{~N}$., R. 31 W., about a mile north of the Shibley gas field, yielded a show of gas. Northwestward from this well the beds rise about 300 feet structurally to the Mulberry fault. The structural rise is closed to the northeast by the 
River Ridge fault and to the southwest by a small fault that joins the Mulberry fault near the center of the south side of sec. $8, T$ T. 9 N., R. $31 \mathrm{~W}$., and trends southeastward for about $1 \frac{1}{2}$ miles from that point. Possibly the three faults have sealed the beds, and gas may be present in the area of structural closure. Wells to test this fold should be drilled to a depth of about 2,200 feet in order to penetrate the producing sands that are present in the nearby Shibley gas field.

\section{SAND AND GRAVEL}

Sand and gravel are produced in Fort Smith and Van Buren, in the western part of the Arkansas coal field. In both places they have been removed from the bed of the Arkansas River by means of dredges, and the supply available is adequate to meet all demands. The materials dredged range in size from gravel to clay. The clay and silt are removed by washing, and the sand and gravel are separated by screening. The gravel is made up of pebbles of quartz, chert, and quartzite, together with occasional fragments of silicified wood and well-cemented sandstone. The sand is clean and is composed of subangular to subrounded fine to coarse grains of quartz. Both the sand and gravel are used locally in making concrete.

\section{SHALE SUITABLE FOR MANUFACTURE OF BRICK}

Several brick plants have used shale in the Atoka, McAlester, and Savanna formations for the manufacture of brick. One plant, that of the Acme Brick Co., of Fort Smith, is still in operation. The shale that has been used for brick is gray, clayey, slightly carbonaceous, and free from nodules or concretions of carbonates, pyrite, or other impurities that might affect the quality of the brick. Paving bricks and common red brick are the only two kinds manufactured.

\section{CRUSHED ROCK}

Sandstone in the McAlester and Savanna formations has been quarried in several places in Fort Smith and crushed for use as road ballast and to a lesser degree for road surfacing. The sandstones that have been quarried are fine-grained, moderately hard, and of low porosity and contain no shale or clay blebs. 
The use of the subjoined mailing label to return this report will be official business, and no postage stamps will be required

\section{UNITED STATES DEPARTMENT OF THE INTERIOR \\ GEOLOGICAL SURVEY \\ OFFICIAL BUSINESS}

This label can be used only for returning official publications. The address must not be changed.

\section{PENALTY FOR PRIVATE USE TO AVOID PAYMENT OF POSTAGE. $\$ 300$}

\section{U. S. GEOLOGICAL SURVEY,}










